Journal of Management

Vol. 44 No. 8, November 2018 3364-3394

DOI: $10.1177 / 0149206316675928$

(C) The Author(s) 2016

Article reuse guidelines:

sagepub.com/journals-permissions

\title{
Proxy Advisors and Shareholder Dissent: A Cross-Country Comparative Study
}

\author{
Steve Sauerwald \\ University of Illinois at Chicago \\ J. (Hans) van Oosterhout \\ Erasmus University \\ Marc Van Essen \\ University of St. Gallen \\ Mike W. Peng \\ University of Texas at Dallas
}

\begin{abstract}
Proxy advisors are information intermediaries that enable shareholders to exercise their voting rights. While proxy advisors' influence is documented in market-based corporate governance systems, we know little about the corporate governance role of proxy advice in relationshipbased governance systems. Drawing on agency theory and the comparative corporate governance literature, we theorize that shareholders are sensitive to the costs and benefits of monitoring by considering internal monitoring capabilities. We also theorize that relative to market-based corporate governance systems, proxy advice is both less influential and has lower predictive quality in relationship-based governance systems. We test our multilevel model using 13,497 voting results from 613 firms in 16 Western European countries and generally find support for our predictions.
\end{abstract}

Keywords: comparative corporate governance; information intermediaries; proxy advisors; shareholder dissent; shareholder voting

\footnotetext{
Acknowledgments: This article was accepted under the editorship of Patrick M. Wright. We appreciate the constructive guidance from Karen Schnatterly (action editor) and three reviewers. We also thank Greg Dess, SeungHyun Lee, John Lin, and Weichieh Su as well as seminar participants at the Rotterdam School of Management, Copenhagen Business School, and University of Wisconsin at Milwaukee for helpful discussions and suggestions. An earlier version of this article was included in abbreviated form in the Best Paper Proceedings of the 2015 Academy of Management Conference (Vancouver, BC).
}

Corresponding author: Steve Sauerwald, Department of Managerial Studies, University of Illinois at Chicago, 601 South Morgan Street, Chicago, IL 60607, USA.

E-mail: ssauerw@uic.edu 
Corporate governance research has predominantly been concerned with assessing the effectiveness of corporate governance mechanisms in reducing the agency costs that result from the separation of ownership and control (Jensen \& Meckling, 1976). To date, this research has focused mainly on the board of directors (Dalton, Daily, Ellstrand, \& Johnson, 1998), ownership structure (Holderness, 2003), and executive compensation (Devers, Cannella, Reilly, \& Yoder, 2007; Sauerwald, Lin, \& Peng, 2016) but has failed to provide unequivocal findings (Dalton, Hitt, Certo, \& Dalton, 2007). As a result of the mixed evidence on the effectiveness of governance practices, scholars are increasingly shifting attention toward activities that shareholders themselves can undertake to remedy agency costs (Goranova \& Ryan, 2014).

Among the various activities that shareholders can engage in to reduce agency costs, shareholder voting is potentially the most powerful course of action (Easterbrook \& Fischel, 1983). Shareholders may use their voting rights not only to veto value-destroying corporate actions (Kraakman et al., 2004) but also to publicly express their dissent by voting against management (David, Bloom, \& Hillman, 2007; David, Hitt, \& Gimeno, 2001; Hillman, Shropshire, Certo, Dalton, \& Dalton, 2011; Sauerwald, van Oosterhout, \& van Essen, 2016). Such expression of shareholder dissent - defined as shareholder votes opposing management's recommendations on proposals put to the vote - is an important antecedent of leadership and governance changes in firms (Cai, Garner, \& Walkling, 2009; Fischer, Gramlich, Miller, \& White, 2009) and is hence a potentially useful governance mechanism to reduce agency costs in public firms (Iliev, Lins, Miller, \& Roth, 2015; Yermack, 2010).

Yet shareholders often lack the incentives to effectively use their voting rights to voice dissent, because they would bear the full costs of expressing dissent but can capture only a fraction of its benefits (Shleifer \& Vishny, 1986). Most shareholders therefore routinely follow management recommendations (Easterbrook \& Fischel, 1983), which saves the costs of expressing dissent but also foregoes any benefits of shareholder dissent (Yermack, 2010).

Prior research has found that shareholders more actively use their voting rights when the potential benefits of dissent increase, such as when shareholders expect it to be effective in disciplining managers (Del Guercio, Seery, \& Woidtke, 2008). For similar reasons, shareholders may be more likely to express their dissent when the costs of voting decrease (Ferri, 2012). While some studies show that shareholders rely on simplifying logics to guide their voting (Hillman et al., 2011; Sauerwald, van Oosterhout, et al., 2016), shareholders may also lower the costs of dissent by relying on information intermediaries (Healy \& Palepu, 2001).

Proxy advisors, such as Institutional Shareholder Services (ISS), are a case in point. As an information intermediary, ISS provides information to shareholders through voting recommendations. Negative voting recommendations - defined as recommendations to vote against management recommendations on proposals put to the vote - can significantly increase shareholder dissent (Alexander, Chen, Seppi, \& Spatt, 2010; Bethel \& Gillan, 2002). Despite its documented efficacy, the corporate governance role of proxy advice is poorly understood.

First, proxy advisors offer their services not only in market-based governance systems, such as the United Kingdom, in which these services originated, but also in more relationshipbased systems of Germany, France, and other continental European countries. Continental Europe provides a challenging environment for proxy advisors because ownership in continental Europe is predominantly in the hands of large blockholders who are able to develop 
internal monitoring capabilities, such as insider information and private access to managers (Faccio \& Lang, 2002; Thomsen \& Pedersen, 2000). Such blockholders are therefore both less dependent on proxy advisors in monitoring managers and less dependent on the public shareholder meeting to express their discontent (Sauerwald, van Oosterhout, et al., 2016).

Second, the failures of other information intermediaries, such as accountants in the corporate scandals at the beginning of the millennium (Sikka, 2009) and the debatable role of credit-rating agencies in the 2008 financial crisis (Partnoy, 2009), have questioned the quality of the services produced by information intermediaries (Coffee, 2006). Similar concerns have been raised against proxy advisors, who allegedly rely too much on rigid "best practices" and public information to identify agency costs and predict the future performance shortfalls that derive from these costs (Larcker, McCall, \& Ormazabal, 2013, 2015).

These observations raise three questions. First, do proxy advisors wield less influence on shareholder dissent in firms that feature strong internal monitoring capabilities (such as those owned by large blockholders) than in firms that lack such internal monitoring capabilities (such as those owned by institutional investors)? Second, do proxy advisors exert less influence on shareholder dissent in relationship-based governance systems than in market-based systems? Third, is the predictive quality of proxy advice similar across relationship-based and market-based governance systems?

To address these questions, we draw on agency theory (Jensen \& Meckling, 1976) and the comparative corporate governance literature (Aguilera, Filatotchev, Gospel, \& Jackson, 2008; Aguilera \& Jackson, 2010). We argue that shareholders are sensitive to the costs and benefits of monitoring (Jacobides \& Croson, 2001) and rely less on proxy advice when internal monitoring capabilities are available. This is because internal monitors can rely on superior private information and behind-the-scenes channels to influence managers. We also argue that proxy advice is less influential in relationship-based governance systems, because the country context shapes the costs and benefits of internal versus external monitoring (Aguilera et al., 2008; Aguilera, Desender, Bednar, \& Lee, 2015). Finally, we argue that providing proxy advisory services in relationship-based governance systems may clash with local country-level conditions that reduce the quality of negative voting recommendations to predict agency costs and the resulting future performance shortfalls, in spite of proxy advisors' advocacy of "global best practices."

We develop and test a multilevel model of the influence and quality of proxy advice in a sample of 13,497 voting results from 613 firms in 16 Western European countries. We focus on Western Europe because it is both economically and institutionally well developed and displays a broad diversity of corporate governance systems (van Essen, van Oosterhout, \& Heugens, 2013; Whitley, 1994). Our cross-country sample enables us to investigate the corporate governance role of proxy advice in a comparative research design.

Overall, we endeavor to make three contributions to the comparative corporate governance literature. First, our findings suggest that shareholders are sensitive to the costs and benefits of internal versus external monitoring and that they appear to substitute external proxy advisory services for the internal monitoring capabilities of large blockholders. Second, our results indicate that the corporate governance role of proxy advice is complementary to the prevailing firm-level and country-level governance conditions. At the firm level, we highlight that the influence of proxy advice increases with the presence of institutional investors in the firm. At the country level, we document that proxy advice has more influence on shareholder dissent in market-based governance systems than in relationship-based systems. Finally, our findings 
suggest that proxy advisors seem to provide higher-quality voting recommendations in market-based governance systems than in relationship-based systems. These findings caution against relying on overly general governance prescriptions.

\section{Theory and Hypotheses}

According to agency theory, the main aim of corporate governance is to minimize the sum of all agency costs that result from the separation of ownership and control, including monitoring costs, bonding costs, and residual losses (Jensen \& Meckling, 1976). Residual losses result from ineffective corporate governance, such as when firms are shielded from the market for corporate control (Dalton et al., 2007). Since our aim is to explain the differential reliance of shareholders on proxy advisors across firms and countries, residual losses are not our main focus. Nor do we focus on bonding costs, which have been the main explanatory focus of the executive compensation literature (Hoskisson, Castleton, \& Withers, 2009). ${ }^{1}$ Instead, we focus on the costs and benefits of relying on internal versus external monitoring, as shareholders face high monitoring costs in exercising their control rights effectively (Goranova \& Ryan, 2014).

For two reasons, shareholder voting is potentially the most powerful control right that shareholders can use to secure their interests in the firm (Easterbrook \& Fischel, 1983). First, shareholders have mandatory consent rights in significant corporate decisions, such as mergers, reincorporations in other jurisdictions, and charter amendments, meaning that they can veto management proposals that seek to change the firm-level "rules of the game" (Bebchuk, 2005). Second, by voting against management, shareholders can publicly challenge the legitimacy of management (Hillman et al., 2011; Sauerwald, van Oosterhout, et al., 2016). As such, the expression of shareholder dissent has been found to lead to changes in the leadership and governance of firms (Cai et al., 2009; Fischer et al., 2009) and is therefore a potentially useful corporate governance mechanism in addressing agency costs (Goranova \& Ryan, 2014; Yermack, 2010).

Empowering shareholders in areas such as shareholder voting has become increasingly important (Bebchuk, 2005; Campbell, Campbell, Sirmon, Bierman, \& Tuggle, 2012; Iliev et al., 2015; Yermack, 2010). Yet, empowering shareholders to resolve agency problems is problematic for firms that are predominantly owned by uninvolved outsiders, such as institutional investors (Franks, Mayer, \& Rossi, 2009). Compared with corporate insiders, outside shareholders are at an informational disadvantage that makes it difficult to identify and address agency costs (Jensen \& Meckling, 1976). Shareholders may circumvent agency costs by investing only in firms with proven and effective corporate governance mechanisms (Bushee, Carter, \& Gerakos, 2013; Gompers, Ishii, \& Metrick, 2003). Yet, many shareholders, such as increasingly popular index funds, are unable to pick investments (Appel, Gormley, \& Keim, 2016) and will therefore need to address agency problems by finding ways to resolve their information problems.

Shareholders may resolve information problems by accumulating or retaining large equity stakes (Shleifer \& Vishny, 1986). Large equity stakes provide incentives to overcome freerider issues and allow shareholders to engage in private behind-the-scenes negotiations with management (Becht, Franks, Mayer, \& Rossi, 2009). Alternatively, shareholders may undertake various activities around the highly public event of a firm's shareholder meeting (Ferri, 2012). Such activities include asking questions, submitting proposals, and voting against 
proposals supported by management (Sauerwald, van Oosterhout, et al., 2016). Even when poorly equipped to vote in an informed way, shareholders may overcome their informational disadvantage by basing their voting on a simplifying agency-theoretical logic (Hillman et al., 2011).

While shareholders have been found to use governance logics to guide their voting (Sauerwald, van Oosterhout, et al., 2016), they may also wish to become informed about the proposals put to the vote at the shareholder meeting (Yermack, 2010). For three reasons, the monitoring costs resulting from collecting and processing information may make it difficult for shareholders to vote. First, shareholders often lack the incentives to collect firm-specific information, because they would bear all the information collection and processing costs but capture only a fraction of the benefits (Shleifer \& Vishny, 1986). Second, shareholders may not have the ability to analyze and process sophisticated information released in proxy and accounting statements (Malmendier \& Shanthikumar, 2007). Third, shareholders' ability to coordinate their voting with other shareholders may also be limited because of the high coordination costs associated with forming shareholder coalitions (Crespi \& Renneboog, 2010).

While some shareholders, such as retail investors, may respond to these informational issues with "rational ignorance" and abstain from voting altogether (Downs, 1957), other shareholders, such as institutional investors, may have a fiduciary duty to vote in an informed way and therefore need to resolve these information problems in a different way (Coffee, 1991; David, Yoshikawa, Chari, \& Rasheed, 2006). In such cases, shareholders may use the services of information intermediaries.

\section{Proxy Advisors and Shareholder Dissent}

Information intermediaries are agents that provide information to reduce information asymmetries between investors and firms (Healy \& Palepu, 2001). Examples include auditors (Sikka, 2009), credit-rating agencies (Partnoy, 2009), and investment analysts (Westphal $\&$ Clement, 2008). Proxy advisors are a relatively new type of information intermediary that offers to resolve voting difficulties in publicly listed firms (Larcker et al., 2015). Their core business is the provision of fee-based voting recommendations on proposals put to the vote to enable shareholders of public firms to exercise their voting rights. These voting recommendations can reduce information asymmetries between firms and their shareholders, because proxy advisors collect, process, and analyze firm-specific information and issue voting recommendations to shareholders. Most importantly, proxy advisors may issue negative voting recommendations to advise shareholders to vote against management proposals (Choi, Fisch, \& Kahan, 2010). Agency theory posits that "any improvement in the principal's information position ought to yield positive results" (Jacobides \& Croson, 2001, p. 204). To the extent that proxy advisors are able to provide cost-efficient information to guide shareholder voting, shareholders may value proxy advice since it lowers their monitoring costs compared to conducting research and voting on their own.

Proxy advisors are able to provide cost-efficient information because they can recover the costs of information processing by selling their services to many investors simultaneously. Because the economies of scale involved in producing these services create significant barriers to entry, ISS has become the globally dominant proxy advisor. In 2012, ISS provided voting recommendations to shareholders at 40,000 shareholder meetings (Larcker, McCall, \& Tayan, 2013), affecting more than \$26 trillion in assets globally (Copland, 2012). 
Four reasons may explain shareholders' reliance on ISS's voting recommendations. First, it is a cost-effective way of acquiring the information needed for informed voting. Although ISS's services are available only on a subscription basis, many shareholders using the service are able to spread its costs over a large number of portfolio firms (Dharwadkar, Goranova, Brandes, \& Khan, 2008).

Second, shareholders may use ISS's negative recommendations to identify crucial proposals that warrant special attention at shareholder meetings (Choi et al., 2010). Given that some shareholders, such as mutual and index funds, vote on thousands of proposals in the relatively short time windows when shareholder meetings are held, ISS's recommendations allow shareholders to focus their attention on the most important proposals (Ocasio, 1997).

Third, shareholders may rely on ISS's negative voting recommendations because they are widely followed by other shareholders. Given that the efficacy of shareholder voting critically depends on how other shareholders vote, shareholders may strategically focus on proposals with a negative ISS voting recommendation because these proposals have a much higher chance of accumulating significant shareholder dissent (Maug \& Rydqvist, 2009).

Finally, the negative voting recommendations provided by ISS may also help to address the agency problems that institutional investors face with their own investors, as these recommendations may legitimize voting decisions (Anabtawi \& Stout, 2008; Pollock \& Rindova, 2003). Shareholders in the United States (Hillman et al., 2011) and Europe (Sauerwald, van Oosterhout, et al., 2016) tend to follow an agency-theoretical logic in their voting, meaning that they are more likely to follow management recommendations if firms espouse governance mechanisms suggested by agency theory. ISS is a close ally of shareholders and incorporates a wide array of shareholder concerns in annual policy reviews (Choi et al., 2010). Similar to how firms espouse an agency-theoretical logic to gain legitimacy among their shareholders (Fiss \& Zajac, 2004), ISS espouses an agency-theoretical logic to appeal to commonly held views of both its subscribers and the investment community more generally (Ferri, 2012). In sum,

Hypothesis 1: Negative voting recommendations by a proxy advisor, such as ISS, are positively related to shareholder dissent.

\section{Firm-Level Contingencies: Ownership Conditions and the Influence of Proxy Advice}

While shareholders may rely on proxy advice due to its cost efficiency, we propose that they also consider the quality of the information involved and the channels through which they may influence management. Specifically, shareholders may substitute external proxy advice for the internal monitoring capabilities of large blockholders (Connelly, Tihanyi, Certo, \& Hitt, 2010), because large blockholders can overcome information problems by acquiring private information and by developing private influence channels. These internal monitoring capabilities allow shareholders to reduce their dependence on proxy advisors, who rely on public information (which may be less informative) as well as shareholder meetings to exercise dissent (which may be less effective). Moreover, shareholders may complement institutional investor ownership of the firm with an increased reliance on proxy advice, because institutional investors as outside shareholders typically lack internal monitoring capabilities that large blockholders can rely on. 
Ownership concentration. Shareholders in dispersedly owned firms face collectiveaction problems and high coordination costs when voting (Easterbrook \& Fischel, 1983). In such firms, internal monitoring capabilities are largely absent. Managers may therefore have leeway to put proposals on the ballot that are potentially value decreasing. Managers may also bundle potentially value-decreasing proposals with value-enhancing proposals (Bethel \& Gillan, 2002) so that shareholders cannot reject these proposals independently. Because dispersed shareholders face severe difficulties screening out value-decreasing proposals before the shareholder meeting, they would need to rely more on external proxy advice and the expression of shareholder dissent at shareholder meetings to influence management (Bebchuk, 2005).

When ownership is more concentrated in the hands of blockholders, however, shareholders can more easily overcome the monitoring and collective-action problems that burden dispersed shareholders (Holderness, 2003). This may be the case in spite of possible agency conflicts between large blockholders and minority shareholders - known as principal-principal (PP) agency problems (Young, Peng, Ahlstrom, Bruton, \& Jiang, 2008). While these PP agency problems may be a cost that shareholders take into account when deciding to rely on blockholder monitoring, the severity of these costs is often contingent on firm-specific factors. Specifically, PP agency problems are likely to be more severe when large shareholders are entrenched (Thomsen, Pedersen, \& Kvist, 2006), when conflicts among blockholders are present (Zellweger \& Kammerlander, 2015), and when blockholders leverage their control rights over and above their cash flow rights (Claessens, Djankov, Fan, \& Lang, 2002). If we account for the firm-specific risk of PP agency problems arising, shareholders may still be more willing to rely on blockholder monitoring over proxy advice because blockholders have both incentives and abilities to collect and process firm-specific information needed for effective monitoring. Given that blockholders are often able to engage privately with management (Becht et al., 2009), they tend to be better informed than dispersed shareholders about controversial management proposals. This ability enables blockholders to screen out value-decreasing proposals from the ballot. Shareholders may thus delegate substantial discretion to blockholders and depend less on external proxy advice to exercise their voting rights (Aghion \& Tirole, 1997). Hence,

Hypothesis 2: Ownership concentration in the firm will moderate the positive relationship between negative voting recommendations and shareholder dissent such that the relationship is less positive when ownership concentration in the firm is high.

Institutional investors. Although the degree of ownership concentration in a firm creates conditions conducive to the development of internal monitoring capabilities that may be a superior substitute for external proxy advice, not all shareholders are equally effective monitors (Thomsen \& Pedersen, 2000). In Europe, different types of shareholders, such as families, governments, and institutional investors, hold sizable ownership stakes (Faccio \& Lang, 2002). These different types of blockholders differ in their incentives and abilities to monitor managers (Thomsen et al., 2006; Yoshikawa, Phan, \& David, 2005).

At the most basic level, we can distinguish inside blockholders who often control and may even actively manage the firm (van Essen et al., 2013) from outside shareholders that only provide equity capital to the firm at arm's length (Connelly et al., 2010). In contrast to inside blockholders, who are typically the ultimate owners of the firm, outside shareholders, such 
as institutional investors, pool funds on behalf of other investors (called fund investors). As institutional investors thereby owe fiduciary duties first and foremost to their fund investors (Johnson, Schnatterly, Johnson, \& Chiu, 2010), institutional investors tend to avoid insider positions (such as board directorships) that would allow them to acquire private information and behind-the-scenes access to management. This is not only because insider positions generate conflicts of interests between their portfolio firms and their fund investors (Bainbridge, 2003) but also because insider positions may compromise the liquidity of their investments through the blackout periods during which insiders cannot trade their shares (Bettis, Coles, \& Lemmon, 2000). While some institutional investors may be able to generate useful firmspecific information from their large ownership position alone (Schnatterly, Shaw, \& Jennings, 2008), most institutional investors are too diversified to effectively monitor any single firm but instead monitor the performance of their investment portfolios as a whole (Dharwadkar et al., 2008; Goranova, Dharwadkar, \& Brandes, 2010). As a result, institutional investors lack the behind-the-scenes access to management that inside blockholders typically possess (Becht et al., 2009). Hence, the larger the ratio of institutional investors in a firm, the less likely that the firm will have strong internal monitoring capabilities and the more likely that its shareholders will complement the dearth of internal monitoring capabilities by increasing their reliance on external proxy advisors. Thus,

Hypothesis 3: Institutional investor ownership in the firm will moderate the positive relationship between negative voting recommendations and shareholder dissent such that the relationship is more positive when institutional investor ownership in the firm is high.

\section{Country-Level Contingencies: Corporate Governance Systems and the Influence and Quality of Proxy Advice}

Research in comparative corporate governance is premised on the idea that corporate governance systems reflect institutions that are static and require country-specific analysis (Aguilera \& Jackson, 2003; David et al., 2006; Fiss \& Zajac, 2004). Yet, proxy advisors may not be appropriately incentivized to provide country-specific analyses and voting recommendations (Veldkamp, 2006). ISS may face difficulties tailoring information to firms in a specific country (Daines, Gow, \& Larcker, 2010; Larcker et al., 2015). Moreover, financial intermediaries may apply governance standards from their home country to other countries, which may clash with local governance standards (Desender, Aguilera, Lopez-Puertas Lamy, \& Crespi, 2016).

Explaining the effects of institutions in a comparative research design is theoretically complex and methodologically complicated. Institutional explanations are often causally complex (Acemoglu, Johnson, \& Robinson, 2001). Not only do they involve many different institutional features (Jackson \& Deeg, 2008), but these features may also combine in many different and complex ways (Fiss, 2007). In addition, institutions may affect governance practices indirectly (Aguilera \& Jackson, 2003) and lead to theoretically unexpected outcomes (Gilson, 2006). Finally, limited variation at the country level often frustrates efforts to appropriately measure and model the effects of discrete institutional features (Fiss, 2007).

To cope with this complexity, we take an approach that compares whole corporate governance systems as a multifaceted institutional context in which corporate governance is embedded (Whitley, 1994). Specifically, we revert to a theoretically robust and empirically 
corroborated distinction between market-based corporate governance systems and relationship-based systems (Peng, 2003), which captures the underlying institutional differences on a single dimension by looking at some of the theoretically most relevant country-level outcomes. This approach is particularly useful to answer our research questions because the costs and benefits of proxy advice depend on the institutional context in which proxy advisors operate (Aguilera et al., 2015; Peng, Sun, Pinkham, \& Chen, 2009).

The influence of proxy advice across corporate governance systems. Market-based corporate governance systems facilitate impersonal exchange between equity market participants and enable shareholders to take up an arm's-length position toward the firms they own. Market-based governance systems enable impersonal arm's-length exchange in at least three ways. First, a market-based governance system must provide sufficient liquidity for shareholders to enter and exit firms at little cost. This is typically the case when equity markets are sufficiently deep and open to foreign investors (Rydqvist, Spizman, \& Strebulaev, 2014). Second, a market-based governance system must provide sufficient safeguards against expropriation of minority shareholders by controlling shareholders, such that controlling shareholders cannot use their private, behind-the-scenes influence to achieve private benefits of control (Young et al., 2008). Third, impersonal arm's-length exchange between equity market participants can take place only when sufficient information is publicly available (Bushman \& Smith, 2001). In such a context, inside blockholders have fewer advantages over outside shareholders because all equity market participants have access to extensive and reliable public information. Shareholders can therefore more safely rely on external proxy advisors to exercise their voting rights, because proxy advisors can cost-effectively analyze the large amounts of public information on behalf of their clients.

In relationship-based governance systems, relational contracting and social networks shape interactions between firms and their environments. The flow of information through these systems may also be significant, but it likely flows in smaller circles and through less public channels (Peng, 2003). For instance, insiders may expropriate minority shareholders through tunneling, propping, and related party transactions (Friedman, Johnson, \& Mitton, 2003), all of which are difficult to observe and to prove in courts due to a lack of public information (Dyck \& Zingales, 2004). Insiders may also reduce the influence of outside directors, making it difficult for proxy advisors to evaluate director effectiveness and allowing insiders to gain private benefits (Peng, 2004; Young et al., 2008). Such conditions make it riskier for shareholders to rely on external proxy advisors, who use public information and the public shareholder meeting to exercise control. We hence expect proxy advice to be more influential when the country's governance system is more market based. Specifically,

Hypothesis 4: The country's governance system will moderate the positive relationship between negative voting recommendations and shareholder dissent such that the relationship is more positive when the country's governance system is more market based.

The predictive quality of proxy advice across corporate governance systems. A particularly interesting reason why shareholders' reliance on external monitoring by proxy advisors differs cross-nationally is that the predictive quality of proxy advice may differ between governance systems (Daines et al., 2010). The main issue at stake is whether proxy advisors can successfully identify residual loss and predict future financial performance shortfalls from 
their monitoring of firms and the proposals put to the vote in these firms (Core, Holthausen, $\&$ Larcker, 1999). Proxy advisors issue a negative voting recommendation when they expect the proposal at stake to increase agency costs in the firm. Negative voting recommendations successfully identify agency costs when these recommendations accurately predict negative future outcomes, such as reduced financial performance (Larcker, McCall, \& Tayan, 2013). Proxy advisors generally argue that their negative recommendations are able to accurately predict future financial performance shortfalls in all country settings. However, proxy advisors often rely on best practices and face potential difficulties tailoring recommendations to specific firm conditions (Daines et al., 2010; Larcker et al., 2015), which may also affect the quality of negative recommendations across countries. We suggest that proxy advisors' negative recommendations are more suitable for market-based corporate governance systems than for relationship-based systems, because proxy advisory services were specifically developed to address the needs of shareholders in market-based systems (Choi, Fisch, \& Kahan, 2009).

Three reasons stand out. First, a U.S.-based proxy advisor, such as ISS, may face substantial challenges in building necessary country-specific monitoring capabilities. This is because proxy advisors may be unable to appropriately consider the unique country conditions outside of their home country and may fail to tailor their recommendations to more relationshipbased governance systems (Kostova, 1999). While this problem may reduce over time as foreign entrants learn (Petersen \& Pedersen, 2002), the incentives for proxy advisors to learn about specific conditions in foreign markets are modest, as their profitability depends on generalizable recommendations that can be sold to many customers across many countries simultaneously (Veldkamp, 2006).

Second, proxy advisors generally rely on firm-specific information that is available from public sources (Ferri, 2012). Yet, private information resulting from behind-the-scenes access to managers tends to be more important to identify governance issues in more relationship-based governance systems (Zaheer \& Venkatraman, 1995). Moreover, firm-specific information is harder to gather in relationship-based governance systems, because the quality of firm disclosures differs across countries and is generally considered to be superior in market-based systems (Bushman, Piotroski, \& Smith, 2004; Peng, 2003). Proxy advisors may therefore find it difficult to elicit useful public information from firms in relationship-based governance systems.

Third, proxy advisors' business model of financing their monitoring activities by selling services to many investors across many countries motivates them to develop standardized voting policies that may not be readily applicable in relationship-based governance systems (Daines et al., 2010; Wellstein \& Kieser, 2011). As a result, we expect ISS negative voting recommendations to better predict agency costs and the resulting future firm performance shortfalls in market-based governance systems. Hence,

Hypothesis 5: The country's governance system will moderate the negative relationship between negative voting recommendations and future firm performance such that the relationship is more negative when the country's governance system is more market based.

\section{Methods}

\section{Data and Sample}

Following calls for more multilevel research in management (Dalton \& Dalton, 2011; Hitt, Beamish, Jackson, \& Mathieu, 2007), we compiled a comprehensive data set with 
Table 1

Sample Overview

\begin{tabular}{lcccccc}
\hline Country & $\begin{array}{c}\text { Number of } \\
\text { Firms }\end{array}$ & $\begin{array}{c}\text { Number of } \\
\text { Proposals }\end{array}$ & $\begin{array}{c}\text { Private Benefits } \\
\text { of Control }\end{array}$ & $\begin{array}{c}\text { Foreign Investor } \\
\text { Ownership }\end{array}$ & $\begin{array}{c}\text { Market } \\
\text { Cap./GDP }\end{array}$ & $\begin{array}{c}\text { Market-Based } \\
\text { Gov. Index }\end{array}$ \\
\hline Austria & 16 & 197 & $38 \%$ & $31 \%$ & $17.5 \%$ & 0.10 \\
Belgium & 15 & 350 & $4 \%$ & $39 \%$ & $33.0 \%$ & 0.57 \\
Finland & 14 & 123 & $2 \%$ & $62 \%$ & $56.8 \%$ & 0.77 \\
France & 105 & 3,678 & $2 \%$ & $41 \%$ & $52.7 \%$ & 0.64 \\
Germany & 77 & 1,658 & $10 \%$ & $21 \%$ & $30.6 \%$ & 0.38 \\
Greece & 12 & 189 & $10 \%$ & $52 \%$ & $26.5 \%$ & 0.57 \\
Ireland & 20 & 370 & $1 \%$ & $67 \%$ & $18.7 \%$ & 0.75 \\
Italy & 56 & 465 & $37 \%$ & $14 \%$ & $22.6 \%$ & 0.01 \\
Luxembourg & 6 & 128 & $5 \%$ & $37 \%$ & $115.0 \%$ & 0.69 \\
Netherlands & 29 & 671 & $2 \%$ & $71 \%$ & $44.6 \%$ & 0.81 \\
Norway & 16 & 289 & $1 \%$ & $41 \%$ & $27.7 \%$ & 0.60 \\
Portugal & 10 & 100 & $20 \%$ & $45 \%$ & $27.3 \%$ & 0.41 \\
Spain & 23 & 481 & $4 \%$ & $37 \%$ & $89.1 \%$ & 0.65 \\
Sweden & 9 & 72 & $7 \%$ & $38 \%$ & $52.0 \%$ & 0.56 \\
Switzerland & 13 & 301 & $6 \%$ & $60 \%$ & $171.4 \%$ & 0.92 \\
United & 192 & 4,425 & $1 \%$ & $40 \%$ & $128.8 \%$ & 0.78 \\
Kingdom & & & & & & \\
Overall & 613 & 13,497 & $9 \%$ & $43 \%$ & $57.1 \%$ & 0.58 \\
\hline
\end{tabular}

Note $:$ Cap. $=$ capitalization; GDP = gross domestic product; Gov. = governance.

three levels of analysis: (a) proposal level, (b) firm level, and (c) country level. This data set allows us to account for the multilevel nature of the relationships that we investigate and also enables us to control for the attributes of the proposals put to the vote (Cai et al., 2009).

First, at the proposal level, we collected data from ISS. ISS collects the voting results for firms listed in the main European stock indexes, such as the SBF 120 in France and the FTSE 350 index in the United Kingdom. The ISS data gave us access to 18,553 proposals at 1,670 shareholder meetings held during the European proxy voting seasons in 2008 and 2009. Second, firm-level variables were manually collected from proxy statements and Thomson Reuters Datastream for each firm-year. Third, country-level variables were collected from various international databases, such as the World Bank and the Federation of European Securities Exchanges (FESE).

After matching the 18,553 proposal-level voting results from ISS with firm-level and country-level data, missing values for firm-level variables reduced our final sample to 13,497 proposal-level observations (Level 1) nested in 613 publicly listed firms (Level 2) and 16 Western European countries (Level 3). Table 1 presents an overview of key country-level differences and sample observations per country.

\section{Dependent Variables}

Shareholder dissent. Following Hillman et al. (2011), shareholder dissent was calculated as the percentage of votes that opposes management's voting recommendation on any 
individual proposal. Management typically recommends voting "for" management-sponsored proposals and "against" shareholder-sponsored proposals. All votes not following management's recommendation are classified as shareholder dissent.

In addition to voting for and against, shareholders may also abstain. In calculating shareholder dissent, we included abstain votes because these votes are cast at the shareholder meeting and hence contribute to fulfilling quorum requirements. Abstain votes also indicate shareholders' skepticism vis-à-vis management (Conyon \& Sadler, 2010). Importantly, abstain votes differ from shares "not voted" because shareholders who do not vote are not counted in the voting outcomes. We log-transformed shareholder dissent since the vote distribution is skewed.

Future firm performance. Two measures of firm performance were used: return on assets (ROA) and Tobin's Q. ROA was measured as total net income divided by total assets. Tobin's Q was measured as the ratio of the year-end market value of the firm's outstanding equity divided by the firm's book value. Both variables were measured with a 1-year forward lag for each firm-year.

\section{Model Variables}

ISS negative recommendation. ISS negative recommendation is a binary variable coded as 1 if ISS advises shareholders to vote against management recommendations and 0 to support management. For Hypothesis 5, we aggregated the number of negative recommendations to the firm-year level by counting the number of negative ISS recommendations during the firm-year divided by the total number of proposals in the firm-year. A larger number of ISS negative recommendations indicates more agency problems identified by ISS in a particular firm-year.

Ownership concentration. We measured ownership concentration as the ratio of shares held by large shareholders to total shares outstanding. It was calculated by subtracting the number of shares owned by shareholders with less than 5\% ownership (also known as "free float") from all outstanding shares at year-end, divided by all outstanding shares at year-end. While some studies have operationalized ownership concentration with the ownership of the largest shareholder (Holderness, 2003; Thomsen \& Pedersen, 2000), we took a finer-grained approach and also considered the ownership of other shareholders (Thomsen et al., 2006). The data were hand-collected from the most recent company filings prior to the shareholder meeting.

Institutional investors. We measured institutional investors as the ratio of shares owned by all investors that pool funds on behalf of other investors to total shares outstanding. Institutional investors in our sample are primarily investment firms, such as BNP Paribas of France, Allianz of Germany, and UBS of Switzerland. While these investment firms also offer other financial services, such as investment banking (e.g., UBS), insurance (e.g., Allianz), and consumer banking (e.g., BNP Paribas), investment management is a sizable share of their business. Ownership information was collected from firm proxy statements and annual reports. 
Market-based governance index. To test Hypotheses 4 and 5, we created an index based on three country-level variables that each capture an aspect of the national corporate governance system. We developed this construct using three variables. First, private benefits of control was obtained from Dyck and Zingales (2004). ${ }^{2}$ This variable measures the extent to which controlling shareholders appropriate financial returns from outside shareholders. High private benefits of control are typical for more relationship-based governance systems because stock markets are underdeveloped (La Porta, Lopez-de-Silanes, Shleifer, \& Vishny, 1997) and many corporate transactions are carried out between trusted partners (Peng, 2003). Second, foreign investor ownership was measured as the country-level percentage of the total share ownership of foreign investors in the focal stock market. The data came from a 2007 survey of the FESE (2008). Foreign shareholders typically condition their investments on developed stock markets (La Porta et al., 1997) and free-market governmental policies (Rydqvist et al., 2014). Thus, foreign shareholders are typically more prevalent in market-based governance systems than in relationship-based systems. Third, stock market capitalization was collected from the World Bank's World Development Indicators. It was calculated as the percentage of market capitalization of listed companies divided by the gross domestic product (GDP) for the current year. High stock market capitalization is a critical determinant of a well-functioning stock market (Morck, Yeung, \& Yu, 2000).

We combined these three variables into an equally weighted index using principal component analysis (PCA; Jackson, 1991). PCA is a useful data reduction technique if no theoretical reason exists to rank order the components of an index (Boyd, Gove, \& Hitt, 2005). We retained one component, which had an eigenvalue of 1.74. Following Larcker, Richardson, and Tuna (2007), we retained this component because all country-level variables had a component loading factor of at least 0.4 . The index ranges on a continuum from relationship-based governance (low index values) to market-based governance (high index values).

\section{Control Variables}

We controlled for the country-level variable institutional ownership/GDP, which reflects the degree of institutional ownership in a country. This was included because ISS may focus its efforts on countries with high institutional ownership. The data came from the Organisation for Economic Co-operation and Development and was scaled by GDP (Gonnard, Kim, \& Ynesta, 2008). Following Iliev et al. (2015), we controlled for countrylevel variables that capture shareholders' ability to cast meaningful dissenting votes against the actions of powerful insiders. First, shareholders may be more likely to cast dissenting votes when they fear expropriation by corporate insiders. We included the anti-self-dealing index, which captures the protection of outside shareholders against expropriation by controlling shareholders. The data were provided by Djankov, La Porta, Lopez-de-Silanes, and Shleifer (2008). Second, effective rule of law may increase the effectiveness of dissenting shareholder votes by increasing the threat of follow-up litigation. We derived rule of law from Freedom House (2010). Third, we controlled for corporate transparency to measure the public availability of firm-specific information. Shareholders may be more inclined to cast dissenting votes in countries that have better disclosures. These data came from Bushman et al. (2004). 
Routine proposal. Following Mallin (1996), proposals to approve the annual report, director elections, profit distributions, share repurchases, discharge of directors, and auditor elections were classified as routine proposals because they are decided at the shareholder meeting annually. Proposals regarding issuance of shares and debt, amendment of company articles, mergers and acquisitions, and share cancellations were considered nonroutine.

Extraordinary meeting. We included a dummy variable that has the value of 1 if the firm had an extraordinary shareholder meeting in a given year and 0 if the firm only had an ordinary annual general shareholder meeting.

Firm size. Larger firms are exposed to higher and more diverse stakeholder expectations, which may result in socially motivated shareholder dissent (Rowley \& Moldoveanu, 2003). We controlled for firm size (the natural logarithm of total assets) as derived from Datastream.

Firm performance. Shareholder dissent may be affected by poor firm performance (Krause, Whitler, \& Semadeni, 2014). We measured firm performance with Tobin's Q (as defined earlier). This variable was measured before the shareholder meeting took place.

Financial leverage. Shareholder activists may voice their dissent to increase the firms' financial leverage (Klein \& Zur, 2009). We measured financial leverage as total debt divided by the book value of total assets derived from Thomson Datastream.

Board size. Because larger boards may be viewed as less effective and attract shareholder dissent (Hillman et al., 2011), we controlled for board size, measured as the number of directors.

CEO duality. CEOs who also chair the board may weaken board monitoring and hence increase shareholder dissent (Dalton et al., 1998). We included a binary variable taking the value 1 if CEO and board chairman position was held by the same individual and 0 otherwise.

CEO tenure. Longer tenured CEOs may be more entrenched and attract shareholder dissent (Dalton et al., 1998). We measured CEO tenure by counting the number of years since the CEO took office.

Two-tier board. Some European countries legislate a two-tier board system consisting of a management board and a supervisory board. We included a binary variable set to 1 if a separate supervisory board exists and 0 otherwise.

Board independence. We measured this variable as the number of nonexecutive directors who have no relationship with the firm divided by the number of all directors.

Largest shareholder ratio. Having several blockholders in the firm may result in mutual monitoring and reduce the opportunities for PP conflicts (Bennedsen \& Wolfenzon, 2000). We included largest shareholder ratio, defined as the ownership of the largest shareholder divided by the ownership of the five largest shareholders combined. This variable ranges 
from 0.2 when the largest shareholder has $1 / 5$ of the ownership of the top 5 shareholders and approaches 1.0 when the largest shareholder is considerably larger than the next four largest shareholders.

Dual-class shares. Dual-class stock separates cash-flow rights from voting rights, which may give insiders opportunities to expropriate outside shareholders (Villalonga \& Amit, 2009). We collected this variable from Factset, taking the value 0 if the firm issued only one type of stock and 1 if the firm issued at least two types of stock with differing voting rights.

\section{Estimation Strategy}

To analyze the influence of proxy advisory services on shareholder dissent as theorized in Hypotheses 1 through 4, we use multilevel modeling (MLM) to account for the hierarchical nature of our data (Hillman et al., 2011; Hitt et al., 2007). While ordinary least squares (OLS) estimation assumes independence between observations, this assumption is violated because higher-level effects constrain the influence of proxy advice across firms (i.e., Level 2; Aguilera et al., 2008) and countries (i.e., Level 3; van Essen et al., 2013). MLM overcomes this limitation by estimating a random intercept for each level and a random coefficient for ISS negative recommendation. The random intercept reflects a change in scale (i.e., shareholder dissent is higher or lower in different firms or countries), while the random coefficient reflects a change in magnitude (i.e., ISS negative recommendation has a stronger or weaker effect across levels). The estimations were performed using the xtmixed command in Stata 14.1.

It is important to determine the appropriate number of random intercepts in MLM models, which can be accomplished by examining the variance in the dependent variable (Raudenbush $\&$ Bryk, 2002). This is important since we have two dependent variables, which may lead to different levels for each dependent variable. For the dependent variable shareholder dissent, significant variance exists on the country and firm-year level. Proposals are clustered within firm-years because shareholders vote on specific proposals, resulting in variation in the dependent variable shareholder dissent at the proposal level. We do not model the firm level as separate random intercept due to the short time dimension of only 2 years in our sample, which may overestimate firm-level variance (Clarke, 2008). We thus specify a three-level model for shareholder dissent, while controlling for firm-level fixed effects.

For the dependent variable future firm performance, however, there is no variation on the proposal level because firm performance is measured at the firm-year level. While some methodological innovations exist to estimate higher-level outcomes with lower-level predictors (Croon \& van Veldhoven, 2007), MLM techniques generally require that the dependent variable is measured at the lowest level (Hofmann, Griffin, \& Gavin, 2000; Preacher, Zyphur, \& Zhang, 2010). We therefore specified a two-level model for the dependent variable future firm performance, while again controlling for firm-level fixed effects. Additionally, the independent variable ISS negative recommendation was aggregated to the firm-year level by counting the number of times ISS negatively recommended against a proposal divided by the total number of proposals in the firm-year. While aggregating data comes with limitations, such as reduced sample size, this aggregation was theoretically mandated (Snijders \& Bosker, 1999).

First, we are theoretically interested in the degree of agency costs identified by ISS for each firm-year, not in the proposal source of agency costs. To test Hypothesis 5, we 
therefore took the number of negative recommendations in each firm-year, scaled by the total number of proposals voted in that firm-year, as a proxy for the degree of agency problems identified by ISS in each firm-year. Second, ecological inference bias (i.e., generalizing findings to an inappropriate lower level) was not a concern as we did not generalize our findings to the proposal level. Rather, our focus was to examine if the level of agency costs identified by ISS was able to predict future performance shortfalls that derive from these agency costs. As we did not theoretically consider the variation in the individual proposals, aggregation is needed.

We group-mean centered ISS negative recommendation at the firm-year level (Hofmann et al., 2000). Group-mean centering was needed to estimate the relationship between the lowest level variables more precisely (Enders \& Tofighi, 2007). It is also required for testing cross-level hypotheses because group-mean centering reduces the between-firm variance in the Level 1 variable, which may lead to spurious cross-level interactions (Enders \& Tofighi, 2007; Hofmann \& Gavin, 1998). Last, we grand-mean centered the higher-level variables to facilitate interpretation and avoid multicollinearity (Raudenbush \& Bryk, 2002, p. 31).

We used maximum-likelihood estimation so we could conduct deviance tests to examine the improvement in model fit (Snijders \& Bosker, 1999). Deviance statistics (defined as -2 times the log likelihood) account for the multilevel nature of errors (Raudenbush \& Bryk, 2002). Similar to examining $R^{2}$ changes in OLS, a statistically significant reduction in deviance upon the stepwise addition of predictor variables indicates model improvement.

\section{Endogeneity Procedure}

ISS negative voting recommendations may be influenced by factors that also influence shareholder dissent, which may raise endogeneity concerns. Specifically, firm performance and corporate governance characteristics, such as board size and board independence, may influence shareholder dissent (Hillman et al., 2011; Krause et al., 2014). These same factors may also influence ISS negative recommendation, because ISS recommends against proposals if the firm's governance characteristics are indicative of agency problems (Cai et al., 2009) and when firm performance is consistently weak (Ertimur, Ferri, \& Oesch, 2013). This raises the question whether negative voting recommendations have an effect on shareholder dissent independent of firm performance and corporate governance characteristics (Cai et al., 2009; Fischer et al., 2009).

Following Cai et al. (2009), we used a two-stage approach in which we created a measure of ISS negative recommendation that is uncorrelated with firm performance and corporate governance characteristics, such as board size and board independence. The residuals derived from the first-stage model are uncorrelated with these factors and will be included in the second-stage MLM models. While this two-stage endogeneity procedure has been used in previous studies to address reverse causation concerns (Cai et al., 2009; Wiersema \& Zhang, 2011), it does not control for omitted-variable bias. We therefore follow Choi et al. (2010) and also control for an extensive list of covariates to account for variables that are correlated with both ISS negative recommendation and shareholder dissent.

Since ISS negative recommendation is a binary endogenous variable, we used a probit regression (see Table 2). To estimate the residuals in nonlinear models, we followed Edmans, Goldstein, and Jiang (2012) by adopting the "generalized residual" for discrete response models. 
Table 2

First-Stage Effects on ISS Negative Recommendation

\begin{tabular}{lcc}
\hline Variable & $\beta$ & $S E$ \\
\hline Intercept & $-2.34^{* * * *}$ & 0.29 \\
Proposal-level variables (Level 1) & & \\
$\quad$ Routine proposal & $-0.16^{* * *}$ & 0.03 \\
Firm-year-level variables (Level 2) & & \\
$\quad$ Extraordinary shareholder meeting & -0.05 & 0.06 \\
Firm size & -0.00 & 0.00 \\
Financial leverage & 0.10 & 0.07 \\
Firm performance & -0.03 & 0.02 \\
Board size & $0.01^{* * *}$ & 0.00 \\
CEO duality & 0.06 & 0.04 \\
CEO tenure & $0.02^{* * *}$ & 0.00 \\
Two-tier board & 0.05 & 0.06 \\
Board independence & -0.08 & 0.11 \\
Largest shareholder ratio & 0.12 & 0.07 \\
Dual-class shares & 0.05 & 0.04 \\
Ownership concentration & $0.99^{* * *}$ & 0.08 \\
Institutional investors & $-0.37^{* *}$ & 0.11 \\
Country-level variables (Level 3) & & \\
Institutional ownership/GDP & $-0.84^{* *}$ & 0.26 \\
Anti-self-dealing index & 0.32 & 0.46 \\
Rule of law & -0.01 & 0.22 \\
Corporate transparency & $-2.04^{* *}$ & 0.63 \\
Market-based governance index & $2.27^{* *}$ & 0.96 \\
Pseudo $R^{2}$ & 0.15 & \\
Wald $\chi^{2}$ & $1,463.06^{* * *}$ & \\
\hline
\end{tabular}

Note: $N_{\text {Level } 1}=13,497 . N_{\text {Level } 2}=1,140 . N_{\text {Level } 3}=16$. Level 1 variables are group-mean centered. Level 2 and Level 3 variables were grand-mean centered. Year effects are included but not reported. ISS = Institutional Shareholder Services; GDP = gross domestic product.

$* p<.05$.

$* * p<.01$.

$* * * p<.001$.

\section{Results}

Table 3 presents descriptive statistics. The correlation coefficients do not raise concerns for multicollinearity. Tests for variance inflation factors are well below the rule-of-thumb value of 10. Table 4 presents our MLM results. Model 1 includes all control variables.

Model 2 includes ISS negative recommendation to test Hypothesis 1 . We find that a negative voting recommendation from ISS increases shareholder dissent $(\beta=0.91, p<.001)$, supporting Hypothesis 1 . In practical terms, a negative ISS recommendation increases shareholder dissent by $148 \%$. Given the average level of shareholder dissent of $3.78 \%$, a negative recommendation from ISS would boost the average level to $9.37 \%$, resulting in an average effect size of $5.59 \%$. This effect size is similar to studies estimating a causal effect of ISS on shareholder dissent - for example, Choi et al. (2010) report an effect size of about $6 \%{ }^{3} \mathrm{~A}$ deviance test indicates significant model fit improvement compared to Model $1, \chi^{2}(1)=811$, $p<.001$, thus justifying the inclusion of ISS negative recommendation. 


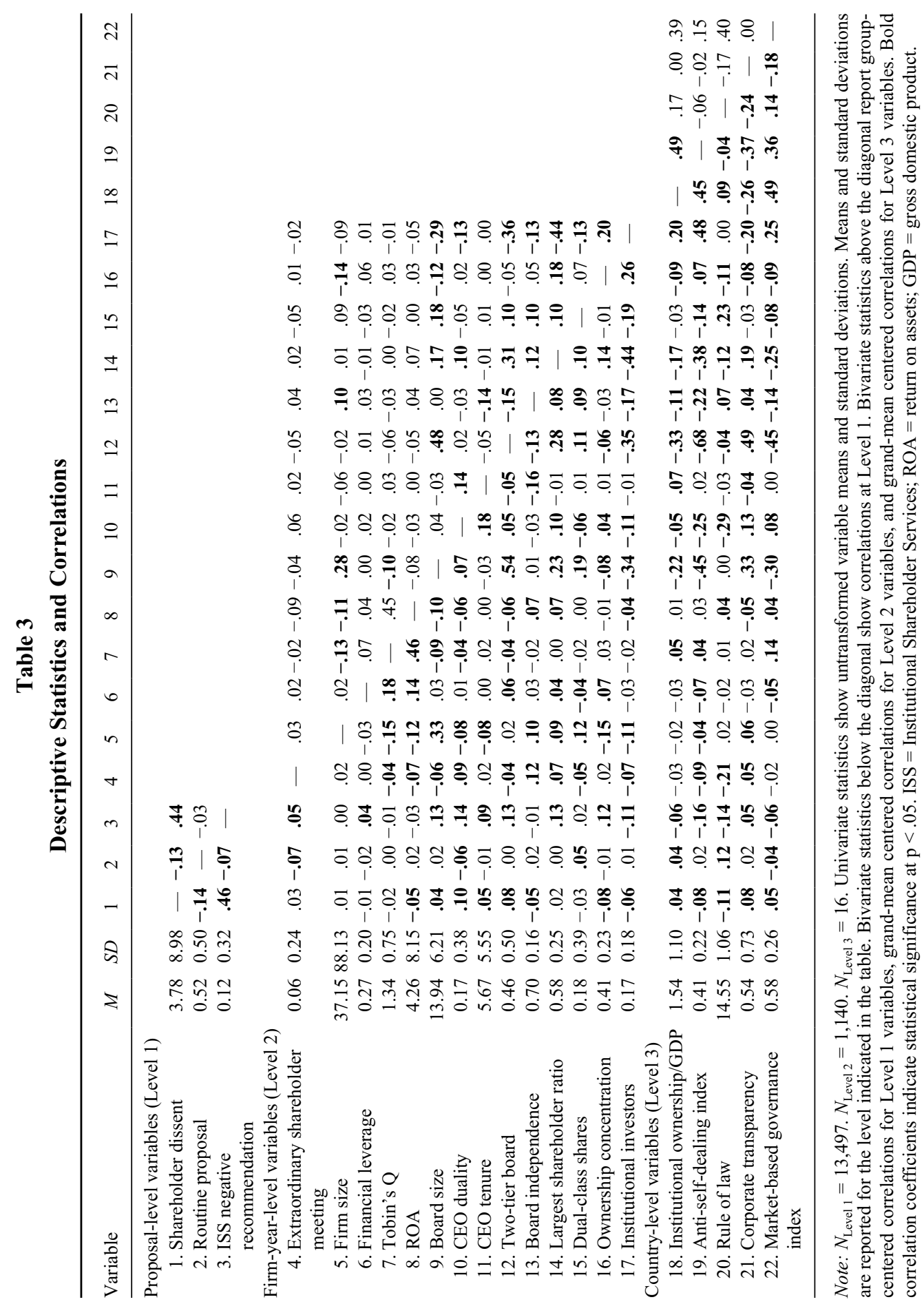


Table 4

Second-Stage Multilevel Regressions: Shareholder Dissent

\begin{tabular}{|c|c|c|c|c|c|c|}
\hline \multirow[b]{2}{*}{ Variable } & \multicolumn{2}{|c|}{ Model 1} & \multicolumn{2}{|c|}{ Model 2} & \multicolumn{2}{|l|}{ Model 3} \\
\hline & $\beta$ & $S E$ & $\beta$ & $S E$ & $\beta$ & $S E$ \\
\hline Intercept & $0.83 * * *$ & 0.17 & $0.85 * * *$ & 0.17 & $0.85^{* * *}$ & 0.17 \\
\hline \multicolumn{7}{|l|}{ Proposal-level variables (Level 1) } \\
\hline Routine proposal & $-0.25 * * *$ & 0.01 & $-0.27 * * *$ & 0.01 & $-0.27 * * *$ & 0.01 \\
\hline \multicolumn{7}{|l|}{ Firm-year-level variables (Level 2) } \\
\hline Extraordinary shareholder meeting & -0.06 & 0.06 & -0.05 & 0.06 & -0.05 & 0.06 \\
\hline Firm size & $0.00 * *$ & 0.00 & $0.00 * *$ & 0.00 & $0.00 * *$ & 0.00 \\
\hline Financial leverage & $0.14^{*}$ & 0.07 & $0.15^{*}$ & 0.07 & $0.15^{*}$ & 0.07 \\
\hline Firm performance & 0.00 & 0.02 & 0.00 & 0.02 & 0.00 & 0.02 \\
\hline Board size & 0.00 & 0.00 & 0.00 & 0.00 & 0.00 & 0.00 \\
\hline CEO duality & 0.05 & 0.04 & 0.04 & 0.04 & 0.04 & 0.04 \\
\hline CEO tenure & -0.00 & 0.00 & -0.00 & 0.00 & -0.00 & 0.00 \\
\hline Two-tier board & -0.01 & 0.06 & -0.03 & 0.06 & -0.03 & 0.06 \\
\hline Board independence & -0.19 & 0.10 & -0.17 & 0.10 & -0.17 & 0.10 \\
\hline Largest shareholder ratio & $-0.14 *$ & 0.07 & $-0.14^{*}$ & 0.07 & $-0.13 *$ & 0.07 \\
\hline Dual-class shares & -0.00 & 0.04 & -0.00 & 0.04 & -0.00 & 0.04 \\
\hline Ownership concentration & $-0.58 * * *$ & 0.07 & $-0.57 * * *$ & 0.07 & $-0.58 * * *$ & 0.07 \\
\hline Institutional investors & -0.09 & 0.10 & -0.09 & 0.10 & -0.08 & 0.10 \\
\hline \multicolumn{7}{|l|}{ Country-level variables (Level 3) } \\
\hline Institutional ownership/GDP & $0.09 *$ & 0.04 & $0.09^{*}$ & 0.04 & $0.09^{*}$ & 0.04 \\
\hline Anti-self-dealing index & -0.17 & 0.20 & -0.19 & 0.20 & -0.19 & 0.21 \\
\hline Rule of law & $-0.14 * * *$ & 0.04 & $-0.14 * * *$ & 0.04 & $-0.14 * * *$ & 0.04 \\
\hline Corporate transparency & 0.04 & 0.06 & 0.05 & 0.06 & 0.05 & 0.06 \\
\hline Market-based governance index & $0.48 * *$ & 0.18 & $0.43 *$ & 0.18 & $0.45^{*}$ & 0.18 \\
\hline \multicolumn{7}{|l|}{ Hypothesis testing } \\
\hline \multicolumn{7}{|l|}{ Proposal-level explanatory variable } \\
\hline $\begin{array}{l}\text { ISS Negative Recommendation } \\
\text { (Hypothesis } 1,+ \text { ) }\end{array}$ & & & $0.91 * * *$ & 0.02 & $0.98 * * *$ & 0.02 \\
\hline \multicolumn{7}{|l|}{ Cross-level interactions } \\
\hline $\begin{array}{l}\text { ISS Negative Recommendation } \times \text { Ownership } \\
\text { Concentration (Hypothesis } 2,- \text { ) }\end{array}$ & & & & & $-0.63 * * *$ & 0.08 \\
\hline $\begin{array}{l}\text { ISS Negative Recommendation } \times \\
\text { Institutional Investors (Hypothesis } 3,+ \text { ) }\end{array}$ & & & & & $0.30 * *$ & 0.10 \\
\hline $\begin{array}{l}\text { ISS Negative Recommendation } \times \text { Market- } \\
\text { Based Governance (Hypothesis } 4,+ \text { ) }\end{array}$ & & & & & $0.63 * * *$ & 0.08 \\
\hline Wald $\chi^{2}$ & $6,082 * * *$ & & $8,282 * * *$ & & $9,094 * * *$ & \\
\hline Deviance & 27,517 & & 26,706 & & 26,569 & \\
\hline$\Delta$ Deviance & & & $811^{* * *}$ & & $137 * * *$ & \\
\hline
\end{tabular}

Note: $N_{\text {Level 1 }}=13,497 . N_{\text {Level 2 }}=1,140 . N_{\text {Level 3 }}=16$. Level 1 variables are group-mean centered. Year effects are included but not reported. ISS negative recommendation is proxied by the general residuals derived from a firststage probit regression. GDP = gross domestic product; ISS = Institutional Shareholder Services.

$* p<.05$.

$* * p<.01$.

$* * * p<.001$.

The cross-level interactions are tested in Model 3. Hypothesis 2 predicts that ISS negative recommendation is less influential when ownership is more concentrated. The coefficient of the interaction term is negative and significant $(\beta=-0.63, p<.001)$. In terms of practical 
significance, increasing ownership concentration from one standard deviation below to one standard deviation above mean ownership concentration decreases the influence of a negative ISS recommendation by around $7.5 \%$. A graphical inspection of this effect supports Hypothesis 2 (Figure 1, Panel A). This figure shows not only the substantial positive main effect of ISS negative recommendation but also that the slope of the regression line is steeper for low ownership concentration. When ownership concentration rises to one standard deviation above the mean, the slope becomes less steep. Thus, Hypothesis 2 is supported.

Hypothesis 3 predicts that when institutional investor ownership is high, ISS negative recommendation will become more influential. The coefficient of the interaction term is significant and positive $(\beta=0.30, p=.003)$. Practically, an increase in institutional investor ownership from one standard deviation below to one standard deviation above its mean increases the influence of ISS by $1.7 \%$. While this increase is less than the moderating influence of ownership concentration, it is still sizable given the average level of shareholder dissent of only 3.78\%. Figure 1 (Panel B) supports this prediction because the slope is steeper when institutional investor ownership is relatively high in a firm. Therefore, Hypothesis 3 is supported.

Hypothesis 4 predicts that the influence of ISS increases in market-based governance systems. Consistent with this prediction, we find a significant and positive interaction term ( $\beta=$ $0.63, p<.001)$. Practically, an increase in the market-based governance index from one standard deviation below to one standard deviation above its mean increases ISS's influence by 4.9\%. This finding supports Hypothesis 4. Figure 1 (Panel C) also supports this hypothesis because the slope of ISS negative recommendation is steeper in more market-based governance systems, such as the United Kingdom, than in less market-based systems, such as Austria.

Table 5 tests Hypothesis 5, predicting that ISS negative recommendations are more negatively related to future firm performance in more market-based governance systems. We find a negative and significant interaction effect of ISS negative recommendations and the market-based governance index predicting ROA in Model $2(\beta=-10.80, p=.019)$ and predicting Tobin's Q in Model 4 ( $\beta=-0.58, p=.009$ ). Figure 1 (Panels D and E) provides further support. ISS negative recommendations in more market-based governance systems have a more negative slope than ISS negative recommendations in less market-based governance systems. Overall, Hypothesis 5 is supported.

\section{Robustness Checks}

We have performed five robustness checks. ${ }^{4}$ First, our primary measure of shareholder dissent includes not only votes against management but also votes abstained (Conyon \& Sadler, 2010; Hillman et al., 2011). To ensure reliability, we exclude abstentions from shareholder dissent. Our results remain similar.

Second, the largest institutional investor in the firm may already have sufficient incentives to actively collect and process information to monitor the firm (Schnatterly et al., 2008). We therefore subtract the largest institutional investor from the overall measure of institutional investors (while separately controlling for the largest institutional investor in the MLM models). The coefficient of the interaction term remains positive and significant.

Third, our MLM models include a dummy variable to identify routine proposals that are voted with a high likelihood at every shareholder meeting. Director elections are typically considered routine proposals, but they also receive much attention from shareholders 
Figure 1

Interaction Graphs

Panel A: Results for Hypothesis 2

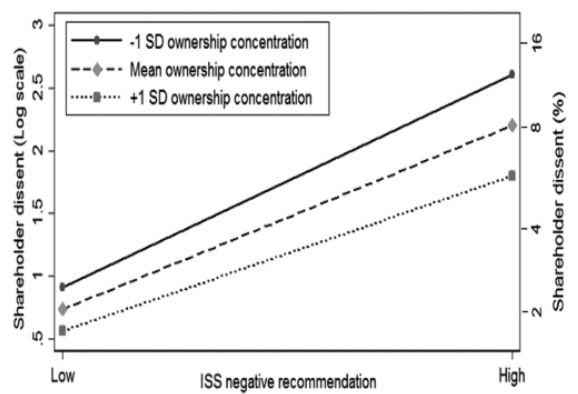

Panel C: Results for Hypothesis 4

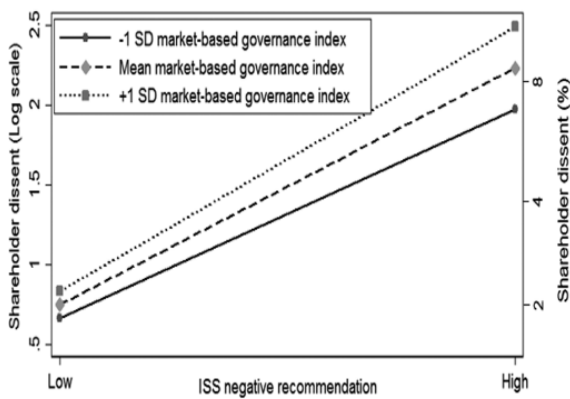

Panel E: Results for Hypothesis 5 (Tobin's Q)

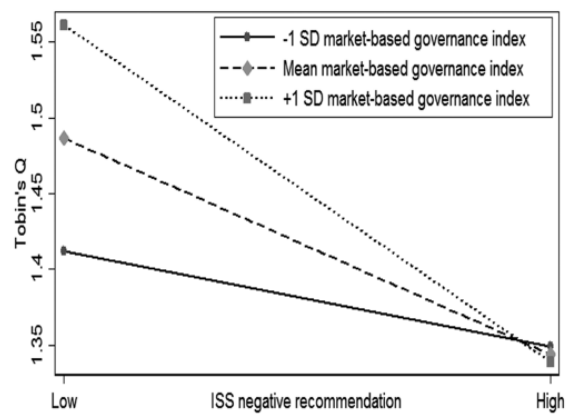

\section{Panel B: Results for Hypothesis 3}

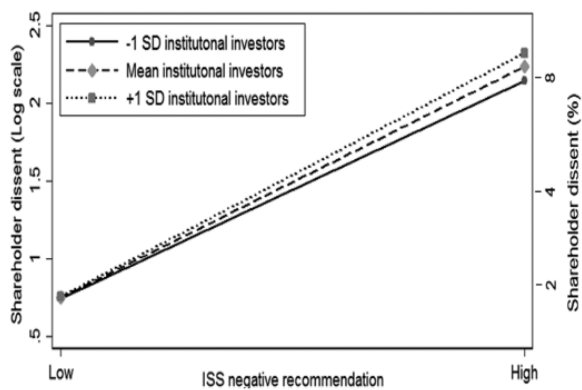

Panel D: Results for Hypothesis 5 (ROA)

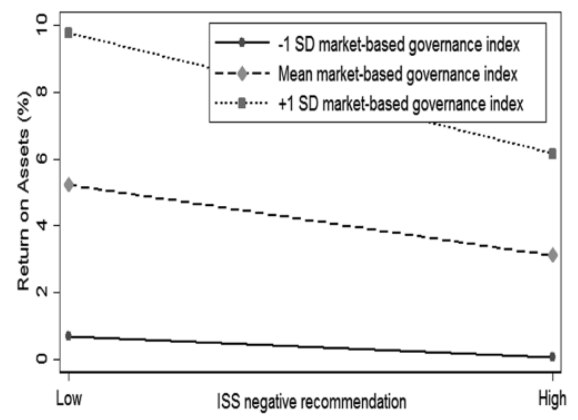

(Hillman et al., 2011), which may affect the level of shareholder dissent. Our results do not change when we classify director elections as nonroutine proposals.

Fourth, some countries in our sample have few firm-level observations but still provide considerable information on the proposal level (e.g., Luxembourg has six firms and 128 proposals). It is generally advised to keep as many observations as possible on the higher levels in MLM models (Snijders \& Bosker, 1999), even if the group size is small (Snijders, 2005, p. 1570). However, our results involving the Level 3 (country-level) variables may be affected due to data sparseness on the firm level (Bell, Morgan, Kromrey, \& Ferron, 2010). Excluding 


\section{Table 5}

Multilevel Regressions: Future Firm Performance

\begin{tabular}{|c|c|c|c|c|c|c|c|c|}
\hline \multirow{2}{*}{$\frac{\text { Model }}{\text { Dependent Variable }}$} & \multicolumn{2}{|c|}{$\begin{array}{l}\text { Model } 1 \text { ROA } \\
\qquad(t+1)\end{array}$} & \multicolumn{2}{|c|}{$\begin{array}{l}\text { Model } 2 \text { ROA } \\
\qquad(t+1)\end{array}$} & \multicolumn{2}{|c|}{$\begin{array}{l}\text { Model } 3 \text { Tobin's Q } \\
\qquad(t+1)\end{array}$} & \multicolumn{2}{|c|}{$\begin{array}{l}\text { Model } 4 \text { Tobin's Q } \\
\qquad(t+1)\end{array}$} \\
\hline & $\beta$ & $S E$ & $\beta$ & $S E$ & $\beta$ & $S E$ & $\beta$ & $S E$ \\
\hline Intercept & 55.51 & 36.31 & 45.80 & 36.46 & 0.00 & 1.72 & -0.49 & 1.73 \\
\hline \multicolumn{9}{|l|}{$\begin{array}{l}\text { Firm-year-level variables } \\
\text { (Level 1) }\end{array}$} \\
\hline Routine proposals & -0.89 & 0.99 & -0.79 & 0.99 & -0.04 & 0.05 & -0.03 & 0.05 \\
\hline $\begin{array}{l}\text { ISS negative } \\
\text { recommendations }\end{array}$ & -1.83 & 1.30 & $-3.57 *$ & 1.50 & $-0.15^{*}$ & 0.06 & $-0.24 * * *$ & 0.07 \\
\hline $\begin{array}{l}\text { Extraordinary } \\
\text { shareholder meeting }\end{array}$ & 0.02 & 1.09 & -0.05 & 1.09 & -0.06 & 0.05 & -0.07 & 0.05 \\
\hline Firm size & 0.01 & 0.01 & 0.01 & 0.01 & 0.00 & 0.00 & 0.00 & 0.00 \\
\hline Financial leverage & 0.26 & 2.86 & 0.23 & 2.86 & -0.03 & 0.13 & -0.04 & 0.13 \\
\hline Board size & 0.12 & 0.06 & 0.12 & 0.06 & $0.01^{*}$ & 0.00 & $0.01 *$ & 0.00 \\
\hline CEO duality & 0.11 & 0.63 & 0.10 & 0.62 & -0.04 & 0.03 & -0.04 & 0.03 \\
\hline CEO tenure & 0.05 & 0.04 & 0.06 & 0.04 & -0.00 & 0.00 & -0.00 & 0.00 \\
\hline Two-tier board & -0.00 & 0.82 & 0.07 & 0.82 & $-0.08^{*}$ & 0.04 & $-0.08^{*}$ & 0.04 \\
\hline Board independence & 0.18 & 1.42 & -0.01 & 1.42 & 0.08 & 0.07 & 0.07 & 0.07 \\
\hline Largest shareholder ratio & $4.57 * *$ & 1.72 & $4.59^{* *}$ & 1.72 & -0.15 & 0.08 & -0.15 & 0.08 \\
\hline Dual-class shares & 3.43 & 3.25 & 3.04 & 3.25 & -0.03 & 0.15 & -0.05 & 0.15 \\
\hline Ownership concentration & 0.67 & 2.35 & 0.27 & 2.35 & $-0.22 *$ & 0.11 & $-0.24 *$ & 0.11 \\
\hline Institutional investors & -0.08 & 3.39 & -0.14 & 3.38 & -0.06 & 0.16 & -0.05 & 0.16 \\
\hline \multicolumn{9}{|l|}{$\begin{array}{l}\text { Country-level variables } \\
\text { (Level 2) }\end{array}$} \\
\hline $\begin{array}{l}\text { Institutional ownership/ } \\
\text { GDP }\end{array}$ & $-9.23 * * *$ & 2.69 & $-9.52 * * *$ & 2.69 & $-0.39 * *$ & 0.13 & $-0.40 * *$ & 0.13 \\
\hline Anti-self-dealing index & 6.91 & 6.11 & 8.16 & 6.12 & $0.60^{*}$ & 0.29 & $0.67 *$ & 0.29 \\
\hline Rule of law & -2.40 & 2.41 & -1.74 & 2.42 & 0.14 & 0.11 & 0.17 & 0.11 \\
\hline Corporate transparency & $-10.31 *$ & 4.74 & $-10.21^{*}$ & 4.73 & $-0.58^{*}$ & 0.22 & $-0.57^{*}$ & 0.22 \\
\hline $\begin{array}{l}\text { Market-based } \\
\text { governance index }\end{array}$ & $16.23 * * *$ & 4.23 & $17.51 * * *$ & 4.26 & 0.14 & 0.20 & 0.21 & 0.20 \\
\hline \multicolumn{9}{|l|}{ Hypothesis testing } \\
\hline $\begin{array}{l}\text { ISS Negative } \\
\text { Recommendations } \\
\times \text { Market-Based } \\
\text { Governance Index } \\
\text { (Hypothesis } 5,- \text { ) }\end{array}$ & & & $-10.80^{*}$ & 4.59 & & & $-0.58^{* *}$ & 0.22 \\
\hline Wald $\chi^{2}$ & $7,144 * * *$ & & $7,184 * * *$ & & $40,274 * * *$ & & $40,514 * * *$ & \\
\hline Deviance & 5,834 & & 5,828 & & 1,127 & & 1,133 & \\
\hline$\Delta$ Deviance & & & $-6^{*}$ & & & & $-6 *$ & \\
\hline
\end{tabular}

Note: $N_{\text {Level } 1}=1,140 . N_{\text {Level } 2}=16$. Firm dummy variables are included to account for firm-level effects. Dependent variables are measured at time $t+1$ while all other variables are measured at time $t$. Year effects are included but not reported. ROA = return on assets; ISS = Institutional Shareholder Services; GDP = gross domestic product.

$* p<.05$.

$* * p<.01$.

$* * * p<.001$. 
observations from the two countries with fewer than 10 firms (Luxembourg and Sweden) does not change our results.

Finally, we test Hypotheses 4 and 5 with three alternative country-level measures for market-based governance systems in unreported analyses. We replace our market-based governance index with the anti-self-dealing index (i.e., shareholder protection against expropriation by controlling shareholders; Djankov et al., 2008) as well as the revised anti-director rights index (i.e., shareholder protection against expropriation by managers and directors; Spamann, 2010). Higher values on these indexes reflect stronger institutional constraints on corporate insiders, which facilitates market-based corporate governance. We also replace our market-based governance index with the coordination index developed by Hall and Gingerich (2009). Higher values on this index reflect institutional conditions resembling relationshipbased governance systems, while lower values reflect market-based systems. Overall, we find similar results using these three alternative country-level variables.

\section{Discussion}

This study started with the question whether the corporate governance role of proxy advice differs between firms and across countries. Leveraging a cross-country sample, we find that the influence of proxy advice on shareholder dissent is conditioned by the ownership composition of firms as well as by the prevailing corporate governance system in a country. At the firm level, we document that shareholders seem to substitute external proxy advice for the internal monitoring capabilities of blockholders that can rely on private information and private access to management, while proxy advice seems complementary to ownership by institutional investors, who typically lack such monitoring capabilities. At the country level, we find that shareholders rely more on external proxy advice in market-based governance systems than in relationship-based systems and that proxy advice appears to be better able to predict future financial performance shortfalls in market-based governance systems than in relationship-based systems. Overall, three contributions to the comparative corporate governance literature emerge.

\section{Substitution Between Internal and External Monitoring}

First, our findings are consistent with the view that shareholders are sensitive to the costs and benefits of internal versus external monitoring and that they prefer to rely on internal monitoring capabilities over external proxy advice. Prior studies have documented similar substitution effects between monitoring and incentive mechanisms (Beatty \& Zajac, 1994; Misangyi \& Acharya, 2014), between blockholder monitoring and board monitoring (Desender, Aguilera, Crespi-Cladera, \& García-Cestona, 2013; Rediker \& Seth, 1995), and between external monitoring by the market for corporate control and internal board monitoring (Sundaramurthy, Mahoney, \& Mahoney, 1997). Contributing to this stream, we provide evidence that substitution effects also exist between external monitoring by proxy advisors and internal monitoring by blockholders.

This finding is noteworthy, because blockholders do not always act in the best interest of minority shareholders. In fact, agency conflicts between controlling and minority shareholders make up the most pressing corporate governance problem in countries where insider 
ownership is the norm (Young et al., 2008). In spite of possible PP agency costs, however, our results suggest that shareholders expect to obtain more value from blockholders' internal monitoring capabilities than they fear losing through expropriation.

This conclusion is consistent with our finding that the presence of a dual-class share structure, which aggravates PP agency problems in blockholder-owned firms (Villalonga \& Amit, 2009), does not significantly affect shareholder dissent. This suggests that at the firm level, shareholders do not see PP agency problems as an inhibiting cost. Yet, our country-level findings show that reliance on proxy advice is lower in relationship-based governance systems where PP agency costs tend to be relatively high (Thomsen et al., 2006), suggesting that PP agency problems may be a bigger cost to shareholders in some countries than in others.

\section{Complementarity Between Proxy Advice and Institutional Investor Ownership}

Our second contribution centers on the complementarity of external proxy advice and institutional investor ownership. We have argued that institutional investors typically lack internal monitoring capabilities because conflicts of interests and liquidity concerns keep them from taking up insider positions, while their often high degree of portfolio diversification stands in the way of developing effective internal monitoring capabilities. Previous studies have suggested that institutional investors have incentives to build internal monitoring capabilities to increase their fund performance (Holland \& Doran, 1998). Yet, this may not always be the case. For instance, only institutional investors with large ownership stakes may have sufficient incentives to develop meaningful information advantages (Schnatterly et al., 2008). Moreover, instead of developing internal monitoring capabilities, institutional investors may rely on generic capabilities, such as stock picking (Nain \& Yao, 2013). Our findings are consistent with this finer-grained research stream. We present arguments and evidence that institutional investor ownership does not decrease the dependence on information intermediaries (as would be expected when institutional investors are able to rely on internal monitoring capabilities similar to large blockholders) but increases the dependence on information intermediaries instead.

\section{Complementarity Between Market-Based Governance Systems and Proxy Advice}

Third, our findings show that proxy advice is more effective in market-based governance systems than in relationship-based systems. These findings echo the central premise of the comparative corporate governance literature that the effectiveness of any individual corporate governance mechanism may depend on the country-level institutional context in which it is deployed (Aguilera \& Jackson, 2010). Specifically, complementarities exist between the corporate governance role of proxy advice and the country-level context in which it operates (Jackson \& Deeg, 2008). Our results suggest that the corporate governance role of proxy advisory services is to an important degree specific to the market-based governance systems in which these services originated. Exporting these services to more relationship-based systems thus poses challenges.

Our study also suggests an important reason as to why the corporate governance role of proxy advice differs between countries. Our findings show that over all sample countries combined, ISS negative voting recommendations are unable to unequivocally identify residual loss 
in firms and predict the resulting future performance shortfalls. This changes once we account for country differences in corporate governance systems. In this finer-grained analysis, proxy advisors are better able to predict future performance shortfalls in more market-based governance systems than in more relationship-based systems. Shareholders may therefore be less concerned with the generic usefulness of proxy advice as a corporate governance mechanism but instead assess its usefulness in specific country contexts (Bebchuk, Cohen, \& Wang, 2013).

\section{Practical Implications}

Both our study as a whole and our finding that the predictive quality of proxy advice differs across contexts suggest that general "best practices" in corporate governance hardly exist (Daines et al., 2010; Haxhi \& van Ees, 2010) and that the quest for globally applicable corporate governance standards may be misguided (Bebchuk \& Hamdani, 2008; Black, de Carvalho, Khanna, Kim, \& Yurtoglu, 2014). Instead, our study suggests that it makes more sense to adjust corporate governance prescriptions to the local conditions in which they are applied (Desender et al., 2016; Fiss \& Zajac, 2004).

Doing so may have three advantages. First, academic research may benefit from the development of corporate governance constructs that capture local conditions by allowing a better identification of causal relationships and a stronger prediction of the degree to which corporate governance mechanisms affect firm value (Black et al., 2014). Second, proxy advisors may benefit from evidence-based adjustments of their voting recommendations to local conditions, which not only will strengthen their corporate governance role across borders but may also secure future business. Finally, managers of firms monitored by proxy advisors may be able to engage more effectively with their shareholders and proxy advisors about the proposals put to the vote and the voting recommendations on these proposals.

\section{Limitations and Future Research}

Our study offers several opportunities for future research. First, our firm-level measures for PP agency costs capture only part of the possible PP agency costs in blockholder-owned firms. While we also control for PP agency costs at the country level as part of the marketbased governance index, future research may further unpack how the costs of blockholder monitoring weigh up to its benefits at the level of the firm.

Second, by operationalizing institutional investors as shareholders that invest in firms on behalf of other shareholders, we have tested only whether conflicts of interests and liquidity concerns prevent institutions from building internal monitoring capabilities but not whether particular types of institutional investors (such as investors with high degree of portfolio diversification or short investment horizons) drive our results (Bushee, 1998; Connelly et al., 2010). As we are unable to measure different degrees of portfolio diversification and different investment horizons for the institutional investors across the 16 countries in our sample due to data availability issues, we must leave the task of further unpacking the effects of institutional investors with different investment strategies on the influence of proxy advice to future research.

Third, while the multilevel design adopted in this study allowed us to empirically tease out firm-level from country-level effects on the influence of proxy advice, we were unable to control for possible causal effects between country-level institutions and firm-level ownership 
conditions that are theoretically plausible in the longer run. As a result, we cannot rule out that some of our findings may be alternatively explained by proxy advisors simply following the gradual change of ownership conditions in our sample countries, for example. Although controlling for the institutional ownership in a country does not suggest that this is the case, we urge future researchers to use more sophisticated causal identification techniques to account for the internationalization patters of proxy advisors.

\section{Conclusion}

Proxy advisors have emerged as useful information intermediaries that facilitate shareholders to exercise their voting rights. But how effective they are in different firm and country contexts has remained unclear to date. In one of the first studies investigating the corporate governance role of proxy advisors across countries, we find that their effectiveness in facilitating shareholder dissent is conditioned by firms' ownership composition as well as the prevailing corporate governance system in a given country. Although proxy advisors are therefore useful aids facilitating shareholder dissent, their effectiveness varies with context.

\section{Notes}

1. In its original agency-theoretical formulation, bonding costs are borne by the agent because agents will need to assure their principals that they will loyally serve their interests (Jensen \& Meckling, 1976). However, the empirical corporate governance literature on bonding has focused mostly on assessing the functioning of executive compensation, and stock- or option-based incentive plans more specifically, as a bonding instrument (Morris, 1987). We thank an anonymous reviewer for calling our attention to this discrepancy.

2. Four countries in our database (Belgium, Greece, Ireland, and Luxembourg) were not considered by Dyck and Zingales (2004), leading us to manually collect the average private benefits from control block purchases from the SDC database following Dyck and Zingales.

3. Malenko and Shen (in press) estimate a causal effect of Institutional Shareholder Services on shareholder dissent of about $25 \%$ but only do so for highly controversial and thus dissent-prone "say-on-pay" proposals.

4. Results are available upon request.

\section{References}

Acemoglu, D., Johnson, S., \& Robinson, J. A. 2001. The colonial origins of comparative development: An empirical investigation. American Economic Review, 91: 1369-1401.

Aghion, P., \& Tirole, J. 1997. Formal and real authority in organizations. Journal of Political Economy, 105: 1-29.

Aguilera, R. V., Desender, K., Bednar, M. K., \& Lee, J. H. 2015. Connecting the dots: Bringing external corporate governance into the corporate governance puzzle. Academy of Management Annals, 9: 483-573.

Aguilera, R. V., Filatotchev, I., Gospel, H., \& Jackson, G. 2008. An organizational approach to comparative corporate governance: Costs, contingencies, and complementarities. Organization Science, 19: 475-492.

Aguilera, R. V., \& Jackson, G. 2003. The cross-national diversity of corporate governance: Dimensions and determinants. Academy of Management Review, 28: 447-465.

Aguilera, R. V., \& Jackson, G. 2010. Comparative and international corporate governance. Academy of Management Annals, 4: 485-556.

Alexander, C. R., Chen, M. A., Seppi, D. J., \& Spatt, C. S. 2010. Interim news and the role of proxy voting advice. Review of Financial Studies, 23: 4419-4454.

Anabtawi, I., \& Stout, L. A. 2008. Fiduciary duties for activist shareholders. Stanford Law Review, 60: 1255-1308.

Appel, I. R., Gormley, T. A., \& Keim, D. B. 2016. Passive investors, not passive owners. Journal of Financial Economics, 121: 111-141. 
Bainbridge, S. M. 2003. Director primacy: The means and ends of corporate governance. Northwestern University Law Review, 97: 547-606.

Beatty, R. P., \& Zajac, E. J. 1994. Managerial incentives, monitoring, and risk bearing: A study of executive compensation, ownership, and board structure in initial public offerings. Administrative Science Quarterly, 39: 313-335.

Bebchuk, L. A. 2005. The case for increasing shareholder power. Harvard Law Review, 118: 833-914.

Bebchuk, L. A., Cohen, A., \& Wang, C. 2013. Learning and the disappearing association between governance and returns. Journal of Financial Economics, 108: 323-348.

Bebchuk, L. A., \& Hamdani, A. 2008. The elusive quest for global governance standards. University of Pennsylvania Law Review, 157: 1263-1317.

Becht, M., Franks, J. R., Mayer, C., \& Rossi, S. 2009. Returns to shareholder activism: Evidence from a clinical study of the Hermes UK focus fund. Review of Financial Studies, 22: 3093-3129.

Bell, B. A., Morgan, G. B., Kromrey, J. D., \& Ferron, J. M. 2010. The impact of small cluster size on multilevel models: A Monte Carlo examination of two-level models with binary and continuous predictors. In JSM Proceedings (pp. 4057-4067). Alexandria, VA: American Statistical Association.

Bennedsen, M., \& Wolfenzon, D. 2000. The balance of power in closely held corporations. Journal of Financial Economics, 58: 113-139.

Bethel, J. E., \& Gillan, S. L. 2002. The impact of the institutional and regulatory environment on shareholder voting. Financial Management, 31: 29-54.

Bettis, J. C., Coles, J. L., \& Lemmon, M. L. 2000. Corporate policies restricting trading by insiders. Journal of Financial Economics, 57: 191-220.

Black, B., de Carvalho, A. G., Khanna, V., Kim, W., \& Yurtoglu, B. 2014. Methods for multicountry studies of corporate governance: Evidence from the BRIKT countries. Journal of Econometrics, 183: 230-240.

Boyd, B. K., Gove, S., \& Hitt, M. A. 2005. Construct measurement in strategic management research: Illusion or reality? Strategic Management Journal, 26: 239-257.

Bushee, B. J. 1998. The influence of institutional investors on myopic R\&D investment behavior. Accounting Review, 73: 305-333.

Bushee, B. J., Carter, M. E., \& Gerakos, J. 2013. Institutional investor preferences for corporate governance mechanisms. Journal of Management Accounting Research, 26: 123-149.

Bushman, R. M., Piotroski, J. D., \& Smith, A. J. 2004. What determines corporate transparency? Journal of Accounting Research, 42: 207-252.

Bushman, R. M., \& Smith, A. J. 2001. Financial accounting information and corporate governance. Journal of Accounting and Economics, 32: 237-333.

Cai, J., Garner, J. L., \& Walkling, R. A. 2009. Electing directors. Journal of Finance, 64: 2389-2421.

Campbell, J. T., Campbell, T. C., Sirmon, D. G., Bierman, L., \& Tuggle, C. S. 2012. Shareholder influence over director nomination via proxy access: Implications for agency conflict and stakeholder value. Strategic Management Journal, 33: 1431-1451.

Choi, S., Fisch, J., \& Kahan, M. 2010. The power of proxy advisors: Myth or reality? Emory Law Journal, 59: 869-918.

Choi, S. J., Fisch, J. E., \& Kahan, M. 2009. Director elections and the role of proxy advisors. Southern California Law Review, 82: 649-701.

Claessens, S., Djankov, S., Fan, J. P. H., \& Lang, L. H. P. 2002. Disentangling the incentive and entrenchment effects of large shareholdings. Journal of Finance, 57: 2741-2771.

Clarke, P. 2008. When can group level clustering be ignored? Multilevel models versus single-level models with sparse data. Journal of Epidemiology and Community Health, 62: 752-758.

Coffee, J. C. 1991. Liquidity versus control: The institutional investor as corporate monitor. Columbia Law Review, 91: $1277-1368$.

Coffee, J. C. 2006. Gatekeepers: The role of the professions and corporate governance. New York: Oxford University Press.

Connelly, B. L., Tihanyi, L., Certo, S. T., \& Hitt, M. A. 2010. Marching to the beat of different drummers: The influence of institutional owners on competitive actions. Academy of Management Journal, 53: 723-742.

Conyon, M., \& Sadler, G. 2010. Shareholder voting and directors' remuneration report legislation: Say on pay in the UK. Corporate Governance: An International Review, 18: 296-312. 
Copland, J. R. 2012. Politicized proxy advisers vs. individual investors. Wall Street Journal, October 7. Retrieved from http://online.wsj.com/article/SB10000872396390444620104578012252125632908.html

Core, J. E., Holthausen, R. W., \& Larcker, D. F. 1999. Corporate governance, chief executive officer compensation, and firm performance. Journal of Financial Economics, 51: 371-406.

Crespi, R., \& Renneboog, L. 2010. Is (institutional) shareholder activism new? Evidence from UK shareholder coalitions in the pre-Cadbury era. Corporate Governance: An International Review, 18: 274-295.

Croon, M. A., \& van Veldhoven, J. P. M. 2007. Predicting group-level outcome variables from variables measured at the individual level: A latent variable multilevel model. Psychological Methods, 12: 45-57.

Daines, R. M., Gow, I. D., \& Larcker, D. F. 2010. Rating the ratings: How good are commercial governance ratings? Journal of Financial Economics, 98: 439-461.

Dalton, D. R., Daily, C. M., Ellstrand, A. E., \& Johnson, J. L. 1998. Meta-analytic reviews of board composition, leadership structure, and financial performance. Strategic Management Journal, 19: 269-290.

Dalton, D. R., \& Dalton, C. M. 2011. Integration of micro and macro studies in governance research: CEO duality, board composition, and financial performance. Journal of Management, 37: 404-411.

Dalton, D. R., Hitt, M. A., Certo, S. T., \& Dalton, C. M. 2007. The fundamental agency problem and its mitigation. Academy of Management Annals, 1: 1-64.

David, P., Bloom, M., \& Hillman, A. J. 2007. Investor activism, managerial responsiveness, and corporate social performance. Strategic Management Journal, 28: 91-100.

David, P., Hitt, M. A., \& Gimeno, J. 2001. The influence of activism by institutional investors on R\&D. Academy of Management Journal, 44: 144-157.

David, P., Yoshikawa, T., Chari, M. D. R., \& Rasheed, A. A. 2006. Strategic investments in Japanese corporations: Do foreign portfolio owners foster underinvestment or appropriate investment? Strategic Management Journal, 27: 591-600.

Del Guercio, D., Seery, L., \& Woidtke, T. 2008. Do boards pay attention when institutional investor activists "just vote no"? Journal of Financial Economics, 90: 84-103.

Desender, K. A., Aguilera, R. V., Crespi-Cladera, R., \& García-Cestona, M. A. 2013. When does ownership matter? Board characteristics and behavior. Strategic Management Journal, 34: 823-842.

Desender, K. A., Aguilera, R. V., Lopez-Puertas Lamy, M., \& Crespi, R. 2016. A clash of governance logics: Foreign ownership and board monitoring. Strategic Management Journal, 37: 349-369.

Devers, C. E., Cannella, A. A., Reilly, G. P., \& Yoder, M. E. 2007. Executive compensation: A multidisciplinary review of recent developments. Journal of Management, 33: 1016-1072.

Dharwadkar, R., Goranova, M., Brandes, P., \& Khan, R. 2008. Institutional ownership and monitoring effectiveness: It's not just how much but what else you own. Organization Science, 19: 419-440.

Djankov, S., La Porta, R., Lopez-de-Silanes, F., \& Shleifer, A. 2008. The law and economics of self-dealing. Journal of Financial Economics, 88: 430-465.

Downs, A. 1957. An economic theory of democracy. New York: Harper and Row.

Dyck, A., \& Zingales, L. 2004. Private benefits of control: An international comparison. Journal of Finance, 59: 537-600.

Easterbrook, F. H., \& Fischel, D. R. 1983. Voting in corporate law. Journal of Law and Economics, 26: 395-427.

Edmans, A., Goldstein, I., \& Jiang, W. 2012. The real effects of financial markets: The impact of prices on takeovers. Journal of Finance, 67: 933-971.

Enders, C. K., \& Tofighi, D. 2007. Centering predictor variables in cross-sectional multilevel models: A new look at an old issue. Psychological Methods, 12: 121-138.

Ertimur, Y., Ferri, F., \& Oesch, D. 2013. Shareholder votes and proxy advisors: Evidence from say on pay. Journal of Accounting Research, 51: 951-996.

Faccio, M., \& Lang, L. H. P. 2002. The ultimate ownership of Western European corporations. Journal of Financial Economics, 65: 365-395.

Federation of European Securities Exchanges. 2008. Share ownership structure in Europe. Brussels: Federation of European Securities Exchanges.

Ferri, F. 2012. "Low cost" shareholder activism: A review of the evidence. In C. A. Hill \& B. H. McDonnell (Eds.), Research handbook on the economics of corporate law: 192-215. Northampton, MA: Edward Elgar.

Fischer, P. E., Gramlich, J. D., Miller, B. P., \& White, H. D. 2009. Investor perceptions of board performance: Evidence from uncontested director elections. Journal of Accounting and Economics, 48: 172-189.

Fiss, P. C. 2007. A set-theoretic approach to organizational configurations. Academy of Management Review, 32: 1180-1198. 
Fiss, P. C., \& Zajac, E. J. 2004. The diffusion of ideas over contested terrain: The (non)adoption of a shareholder value orientation among German firms. Administrative Science Quarterly, 49: 501-534.

Franks, J., Mayer, C., \& Rossi, S. 2009. Ownership: Evolution and regulation. Review of Financial Studies, 22 : 4009-4056.

Freedom House. 2010. Country rankings of political rights and civil liberties. Washington, DC: Freedom House.

Friedman, E., Johnson, S., \& Mitton, T. 2003. Propping and tunneling. Journal of Comparative Economics, 31: $732-750$.

Gilson, R. J. 2006. Controlling shareholders and corporate governance: Complicating the comparative taxonomy. Harvard Law Review, 119: 1641-1679.

Gompers, P., Ishii, J., \& Metrick, A. 2003. Corporate governance and equity prices. Quarterly Journal of Economics, 118: 107-155.

Gonnard, E., Kim, E. J., \& Ynesta, I. 2008. Recent trends in institutional investors statistics. Paris: Organisation for Economic Co-operation and Development.

Goranova, M., Dharwadkar, R., \& Brandes, P. 2010. Owners on both sides of the deal: Mergers and acquisitions and overlapping institutional ownership. Strategic Management Journal, 31: 1114-1135.

Goranova, M., \& Ryan, L. V. 2014. Shareholder activism: A multidisciplinary review. Journal of Management, 40: 1230-1268.

Hall, P. A., \& Gingerich, D. W. 2009. Varieties of capitalism and institutional complementarities in the political economy: An empirical analysis. British Journal of Political Science, 39: 449-482.

Haxhi, I., \& van Ees, H. 2010. Explaining diversity in the worldwide diffusion of codes of good governance. Journal of International Business Studies, 41: 710-726.

Healy, P. M., \& Palepu, K. G. 2001. Information asymmetry, corporate disclosure, and the capital markets: A review of the empirical disclosure literature. Journal of Accounting and Economics, 31: 405-440.

Hillman, A. J., Shropshire, C., Certo, S. T., Dalton, D. R., \& Dalton, C. M. 2011. What I like about you: A multilevel study of shareholder discontent with director monitoring. Organization Science, 22: 675-687.

Hitt, M. A., Beamish, P. W., Jackson, S. E., \& Mathieu, J. E. 2007. Building theoretical and empirical bridges across levels: Multilevel research in management. Academy of Management Journal, 50: 1385-1399.

Hofmann, D. A., \& Gavin, M. B. 1998. Centering decisions in hierarchical linear models: Implications for research in organizations. Journal of Management, 24: 623-641.

Hofmann, D. A., Griffin, M. A., \& Gavin, M. B. 2000. The application of hierarchical linear modeling to management research. In K. J. Klein \& S. W. J. Kozlowski (Eds.), Multilevel theory, research, and methods in organizations: Foundations, extensions, and new directions: 467-511. San Francisco: Jossey-Bass.

Holderness, C. G. 2003. A survey of blockholders and corporate control. Economic Policy Review, 9: 51-63.

Holland, J. B., \& Doran, P. 1998. Financial institutions, private acquisition of corporate information, and fund management. European Journal of Finance, 4: 129-155.

Hoskisson, R. E., Castleton, M. W., \& Withers, M. C. 2009. Complementarity in monitoring and bonding: More intense monitoring leads to higher executive compensation. Academy of Management Perspectives, 23: 57-74.

Iliev, P., Lins, K. V., Miller, D. P., \& Roth, L. 2015. Shareholder voting and corporate governance around the world. Review of Financial Studies, 28: 2167-2202.

Jackson, G., \& Deeg, R. 2008. Comparing capitalisms: Understanding institutional diversity and its implications for international business. Journal of International Business Studies, 39: 540-561.

Jackson, J. E. 1991. A user's guide to principal components. Hoboken, NJ: Wiley-Interscience.

Jacobides, M. G., \& Croson, D. C. 2001. Information policy: Shaping the value of agency relationships. Academy of Management Review, 26: 202-223.

Jensen, M. C., \& Meckling, W. H. 1976. Theory of the firm: Managerial behavior, agency costs and ownership structure. Journal of Financial Economics, 3: 305-360.

Johnson, R. A., Schnatterly, K., Johnson, S. G., \& Chiu, S.-C. 2010. Institutional investors and institutional environment: A comparative analysis and review. Journal of Management Studies, 47: 1590-1613.

Klein, A., \& Zur, E. 2009. Entrepreneurial shareholder activism: Hedge funds and other private investors. Journal of Finance, 64: 187-229.

Kostova, T. 1999. Transnational transfer of strategic organizational practices: A contextual perspective. Academy of Management Review, 24: 308-324.

Kraakman, R. H., Davies, P., Hansmann, H., Hertig, G., Hopt, K., Kanda, H., \& Rock, E. B. (Eds.). 2004. The anatomy of corporate law: A comparative and functional approach. New York: Oxford University Press. 
Krause, R., Whitler, K., \& Semadeni, M. 2014. Power to the principals! An experimental look at shareholder sayon-pay voting. Academy of Management Journal, 57: 94-115.

La Porta, R., Lopez-de-Silanes, F., Shleifer, A., \& Vishny, R. W. 1997. Legal determinants of external finance. Journal of Finance, 52: 1131-1150.

Larcker, D. F., McCall, A. L., \& Ormazabal, G. 2013. Proxy advisory firms and stock option repricing. Journal of Accounting and Economics, 56: 149-169.

Larcker, D. F., McCall, A. L., \& Ormazabal, G. 2015. Outsourcing shareholder voting to proxy advisory firms. Journal of Law \& Economics, 58: 173-204.

Larcker, D. F., McCall, A. L., \& Tayan, B. 2013. And then a miracle happens! How do proxy advisory firms develop their voting recommendations? Stanford, CA: Stanford University. Retrieved from http://papers.ssrn. com/abstract $=2224329$

Larcker, D. F., Richardson, S. A., \& Tuna, I. 2007. Corporate governance, accounting outcomes, and organizational performance. Accounting Review, 82: 963-1008.

Malenko, N., \& Shen, Y. in press. The role of proxy advisory firms: Evidence from a regression-discontinuity design. Review of Financial Studies.

Mallin, C. A. 1996. The voting framework: A comparative study of voting behaviour of institutional investors in the U.S. and the U.K. Corporate Governance: An International Review, 4: 107-122.

Malmendier, U., \& Shanthikumar, D. 2007. Are small investors naive about incentives? Journal of Financial Economics, 85: 457-489.

Maug, E., \& Rydqvist, K. 2009. Do shareholders vote strategically? Voting behavior, proposal screening, and majority rules. Review of Finance, 13: 47-79.

Misangyi, V. F., \& Acharya, A. G. 2014. Substitutes or complements? A configurational examination of corporate governance mechanisms. Academy of Management Journal, 57: 1681-1705.

Morck, R., Yeung, B., \& Yu, W. 2000. The information content of stock markets: Why do emerging markets have synchronous stock price movements? Journal of Financial Economics, 58: 215-260.

Morris, R. D. 1987. Signalling, agency theory and accounting policy choice. Accounting and Business Research, 18: 47-56.

Nain, A., \& Yao, T. 2013. Mutual fund skill and the performance of corporate acquirers. Journal of Financial Economics, 110: 437-456.

Ocasio, W. 1997. Towards an attention-based view of the firm. Strategic Management Journal, 18: 187-206.

Partnoy, F. 2009. Historical perspectives on the financial crisis: Ivar Kreuger, the credit-rating agencies, and two theories about the function, and dysfunction, of markets. Yale Journal on Regulation, 26: 431-443.

Peng, M. W. 2003. Institutional transitions and strategic choices. Academy of Management Review, 28: 275-296.

Peng, M. W. 2004. Outside directors and firm performance during institutional transitions. Strategic Management Journal, 25: 453-471.

Peng, M. W., Sun, S. L., Pinkham, B., \& Chen, H. 2009. The institution-based view as a third leg for a strategy tripod. Academy of Management Perspectives, 23: 63-81.

Petersen, B., \& Pedersen, T. 2002. Coping with liability of foreignness: Different learning engagements of entrant firms. Journal of International Management, 8: 339-350.

Pollock, T. G., \& Rindova, V. P. 2003. Media legitimation effects in the market for initial public offerings. Academy of Management Journal, 46: 631-642.

Preacher, K. J., Zyphur, M. J., \& Zhang, Z. 2010. A general multilevel SEM framework for assessing multilevel mediation. Psychological Methods, 15: 209-233.

Raudenbush, S. W., \& Bryk, A. S. 2002. Hierarchical linear models: Applications and data analysis methods (2nd ed.). Thousand Oaks, CA: Sage.

Rediker, K. J., \& Seth, A. 1995. Boards of directors and substitution effects of alternative governance mechanisms. Strategic Management Journal, 16: 85-99.

Rowley, T. J., \& Moldoveanu, M. 2003. When will stakeholder groups act? An interest-and identity-based model of stakeholder group mobilization. Academy of Management Review, 28: 204-219.

Rydqvist, K., Spizman, J., \& Strebulaev, I. 2014. Government policy and ownership of equity securities. Journal of Financial Economics, 111: 70-85.

Sauerwald, S., Lin, Z., \& Peng, M. W. 2016. Board social capital and excess CEO returns. Strategic Management Journal, 37: 498-520.

Sauerwald, S., van Oosterhout, J., \& van Essen, M. 2016. Expressive shareholder democracy: A multilevel study of shareholder dissent in 15 Western European countries. Journal of Management Studies, 53: 520-551. 
Schnatterly, K., Shaw, K. W., \& Jennings, W. W. 2008. Information advantages of large institutional owners. Strategic Management Journal, 29: 219-227.

Shleifer, A., \& Vishny, R. W. 1986. Large shareholders and corporate control. Journal of Political Economy, 94: 461-488.

Sikka, P. 2009. Financial crisis and the silence of the auditors. Accounting, Organizations and Society, 34: 868-873.

Snijders, T. A. B. 2005. Power and sample size in multilevel linear models. In B. S. Everitt \& D. Howell (Eds.), Encyclopedia of statistics in behavioral science: 1570-1573. Hoboken, NJ: Wiley.

Snijders, T. A. B., \& Bosker, R. J. 1999. Multilevel analysis: An introduction to basic and advanced multilevel modeling. Thousand Oaks, CA: Sage.

Spamann, H. 2010. The "antidirector rights index" revisited. Review of Financial Studies, 23: 467-486.

Sundaramurthy, C., Mahoney, J. M., \& Mahoney, J. T. 1997. Board structure, antitakeover provisions, and stockholder wealth. Strategic Management Journal, 18: 231-245.

Thomsen, S., \& Pedersen, T. 2000. Ownership structure and economic performance in the largest European companies. Strategic Management Journal, 21: 689-705.

Thomsen, S., Pedersen, T., \& Kvist, H. K. 2006. Blockholder ownership: Effects on firm value in market and control based governance systems. Journal of Corporate Finance, 12: 246-269.

van Essen, M., van Oosterhout, J., \& Heugens, P. P. M. A. R. 2013. Competition and cooperation in corporate governance: The effects of labor institutions on blockholder effectiveness in 23 European countries. Organization Science, 24: 530-551.

Veldkamp, L. L. 2006. Information markets and the comovement of asset prices. Review of Economic Studies, 73: $823-845$.

Villalonga, B., \& Amit, R. 2009. How are U.S. family firms controlled? Review of Financial Studies, 22: $3047-3091$.

Wellstein, B., \& Kieser, A. 2011. Trading "best practices": A good practice? Industrial and Corporate Change, 20: 683-719.

Westphal, J. D., \& Clement, M. B. 2008. Sociopolitical dynamics in relations between top managers and security analysts: Favor rendering, reciprocity, and analyst stock recommendations. Academy of Management Journal, 51: 873-897.

Whitley, R. 1994. European business systems: Firms and markets in their national contexts. London: Sage.

Wiersema, M. F., \& Zhang, Y. 2011. CEO dismissal: The role of investment analysts. Strategic Management Journal, 32: 1161-1182.

Yermack, D. 2010. Shareholder voting and corporate governance. Annual Review of Financial Economics, 2: $103-$ 125.

Yoshikawa, T., Phan, P. H., \& David, P. 2005. The impact of ownership structure on wage intensity in Japanese corporations. Journal of Management, 31: 278-300.

Young, M. N., Peng, M. W., Ahlstrom, D., Bruton, G. D., \& Jiang, Y. 2008. Corporate governance in emerging economies: A review of the principal-principal perspective. Journal of Management Studies, 45: 196-220.

Zaheer, A., \& Venkatraman, N. 1995. Relational governance as an interorganizational strategy: An empirical test of the role of trust in economic exchange. Strategic Management Journal, 16: 373-392.

Zellweger, T., \& Kammerlander, N. 2015. Family, wealth, and governance: An agency account. Entrepreneurship Theory and Practice, 39: 1281-1303. 